\title{
State Taxation of Interstate Business and the Supreme Court, 1974 Term: Standard Pressed Steel and Colonial Pipeline
}

Walter Hellerstein

University of Georgia School of Law, wallyh@uga.edu

b

\section{Repository Citation}

Walter Hellerstein, State Taxation of Interstate Business and the Supreme Court, 1974 Term: Standard Pressed Steel and Colonial Pipeline (1976),

Available at: https://digitalcommons.law.uga.edu/fac_artchop/380

This Article is brought to you for free and open access by the Faculty Scholarship at Digital Commons @ University of Georgia School of Law. It has been accepted for inclusion in Scholarly Works by an authorized administrator of Digital Commons @ University of Georgia School of Law. Please share how you have benefited from this access For more information, please contact tstriepe@uga.edu. 


\title{
STATE TAXATION OF INTERSTATE BUSINESS AND THE SUPREME COURT, 1974 TERM: STANDARD PRESSED STEEL AND COLONIAL PIPELINE
}

\author{
Walter Hellerstein *
}

SOME years ago, the Supreme Court explicitly recognized that $\checkmark$ efforts to reconcile its hundreds of decisions delineating the scope of state tax power over interstate business would be pointless ${ }^{1}$ if not altogether futile. ${ }^{2}$ This uncharacteristic display of candor hardly signaled the dawn of a new era of judicial consciousnessraising. ${ }^{3}$ Nevertheless, it reflected the Court's awareness that

- Assistant Professor of Law, The University of Chicago.

1 Speaking of the limitations imposed on state tax power by the commerce clause, the Court declared:

The history of this problem is spread over hundreds of volumes of our Reports. To attempt to harmonize all that has been said in the past would neither clarify what has gone before nor guide the future.

Freeman v. Hewit, 329 U.S. 249, 252 (1946).

2 Addressing the constitutional inhibitions on the states' power to collect a use tax from an out-of-state vendor, the Court stated:

Despite the increasing frequency with which the question arises, little constructive discussion can be found in responsible commentary as to the grounds on which to rest a state's power to reach extraterritorial transactions or nonresidents with tax liabilities. Our decisions are not always clear as to the grounds on which a tax is supported, especially where more than one exists; nor are all of our pronouncements ... consisteut or reconcilable.

Miller Bros. v. Maryland, 347 U.S. 340, 344 (1954). See also Northwestern States Portland Cement Co. v. Minnesota, 358 U.S. 450, 458 (1959). The problem inspired one state court to wax classical:

It would be a Herculean, if not impossible task, to review and harmonize the myriad decisions of the Supreme Court of the United States on the subject of interstate commerce and exactly what incidents thereof may be constitutionally taxed by the States. The dissenting opinions in many of those cases make clear that the task of reconciling all the decisions is more difficult than was the task of Theseus as he threaded his way through the famous Cretan Labyrinth in search of the Minotaur.

Ro! Stone Transfer Corp. v. Messner, 377 Pa. 234, 243-44, 103 A.2d 700, 705 (1954).

3 Indeed, Freeman v. Hewit, 329 U.S. 249 (1946), was roundly condemned as further muddying the waters by "marking a recrudescence of the old, mechanical and meaningless terminology," P. Hartman, State Taxation of Interstate Commerce 201 (1953), and as "abandoning new for thoroughly criticized old," Dunham, Gross Receipts Taxes on Interstate Transactions, 47 Colum. L. Rev. 211, 212 (1947); and Miller Bros. v. Maryland, 347 
particular precedents in this area of the law often represented little more than tentative and fragile accommodations between competing state and national interests worked out by justices with widely varying views on how to resolve these conflicts. ${ }^{4}$ Indeed, it would have been difficult to ignore the doctrinal instability that marked the Court's opinions. The pendulum had swung from the formal and restrictive "direct-indirect" burdens approach that dominated the Court's thinking in the early part of this century ${ }^{5}$ to the more practical and liberalized "multiple burdens" theory developed by Justices Stone and Rutledge in the late 1930's, ${ }^{6}$ only to swing back

U.S. 340, 346 (1954), stigmatized a result the Court had sanctioned just ten years earlier as "strange law." Compare id. with McLeod v. J.E. Dilworth Co., 322 U.S. 327 (1944). See also Strecker, "Local Incidents" of Interstate Business, 18 Oнго ST. L.J. 69, 81 (1957).

4 P. Hartman, supra note 3, at 21-48; J. Hellerstein, Stite and Local TaxATION 163-70 (3d ed. 1969).

5 Taxes the Court construed as imposing "direct" burdens on interstate commerce were struck down; those it construed as "indirectly" affecting interstate commerce were upheld. See, e.g., Robbins v. Shelby County Taxing Dist., 120 U.S. 489 (1887) ; Crew Levick Co. v. Pennsylvania, 245 U.S. 292 (1917); Postal Tel.-Cable Co. v. City of Richmond, 249 U.S. 252 (1919). See generally P. Hartman, supra note 3, at 28-33; J. Hellerstein, supra note 4 , at $165-66$.

6 While there were some earlier clues, see Di Santo v. Pennsylvania, 273 U.S. 34, 44 (1927) (Stone, J., dissenting); Helson \& Randolph v. Kentucky, 279 U.S. 245, 252-53 (1929) (Stone, J., concurring) . Justice Stone's assault on the "direct-indirect burdens" rubric as a meaningless and unsatisfactory method for determining the validity of a state tax under the commerce clause and his attempt to replace it with a "multiple burdens" test as a more practical alternative began in Western Live Stock v. Bureau of Revenue, 303 U.S. 250 (1938). In Western Live Stock, involving a New Mexico gross receipts tax on a magazine publisber, Justice Stone stated:

[W] think the tax assailed here finds support in reason, and in the practical needs of a taxing system which, under constitutional limitations, must accommodate itself to the double demand that interstate business shall pay its way, and that at the same time it shall not be burdened with cumulative exactions which are not similarly laid on local business. ...

The tax is not one which in form or substance can be repeated by other states in such manner as to lay an added burden on tbe interstate distribution of the magazine. ...

Id. at 258, 260. Justice Stone continued his efforts with varying degrees of emphasis and success in Gwin, White \& Prince, Inc. v. Henneford, 305 U.S. 434 (1939) ; McGoldrick v. Berwind-White Coal Mining Co., 309 U.S. 33 (1940); and Northwest Airlines, Inc. v. Minnesota, 322 U.S. 292, 308-26 (1944) (Stone, C.J., dissenting) . See generally P. Harman, supra note 3, at 33-40; Wechsler, Stone and the Constitution, 46 Colum. L. Rev. 764, 785-90 (1946).

Justice Rutledge's tonr de force in this enterprise appears in his opinion concurring and dissenting in the companion cases of McLeod v. J.E. Dilworth Co., 322 U.S. 327 (1944); General Trading Co. v. State Tax Comm'n, 322 U.S. 335 (1944); and International Harvester Co. v. Department of Treasury, 322 U.S. 340 (1944). Id. at 349-62 (Rutledge, J., 
again ${ }^{7}$-but not completely ${ }^{8}$-to the earlier doctrine in the late 1940's. In the 1950's, the Court took an approach that may charitably be described as eclectic, as it drew freely ${ }^{9}$ (and perhaps indiscriminately ${ }^{10}$ ) from prior opinions.

Then in 1959 the Court handed down its celebrated decision in Northwestern States Portland Cement Co. v. Minnesota, ${ }^{11}$ holding that a state could constitutionally impose a nondiscriminatory, fairly apportioned net income tax on a foreign corporation engaged in exclusively interstate commerce in the state. The ruling provoked a vigorous reaction from various quarters. Businessmen, fearing the strengthened hand and extended reach of the state tax

concurring and dissenting). McLeod struck down an Arkansas sales tax on "sales made by Tennessee vendors that are consummated in Tennessee for the delivery of goods in Arkansas." 322 U.S. at 328. General Trading upheld Iowa's power to collect a use tax from a Minnesota vendor on property it sold to Iowa purchasers through orders solicited by traveling salesman but accepted in and sent from Minnesota. 322 U.S. at 337. International Harvester upheld Indiana's gross income tax over three classes of sales transactions involving goods delivered to Indiana customers from an out-of-state origin, or conversely delivered to an out-of-state customer in Indiana. 322 U.S. at 342. Justice Rutledge, expounding on the "multiple burden" doctrine, would have upheld the taxes on the ground that none of the levies was imposed in violation of the following principle:

[T] he state may not impose certain taxes on interstate commerce, its incidents or instrumentalities, which are no more in amount or burden than it places on its local business, not because this of itself is discriminatory, cumulative or special or would violate due process, but because other states also may have the right constitutionally, apart from the commerce clause, to tax the same thing and either the actuality or the risk of their doing so makes the total burden cumulative, discriminatory or special.

Id. at 358 (citation omitted). See also Freeman v. Hewit, 329 U.S. 249, 259-83 (1946) (Rutledge, J., concurring) ; Memphis Natural Gas Co. v. Stone, 335 U.S. 80, 96-99 (1948) (Rutledge, J., concurring).

7 Freeman v. Hewit, 329 U.S. 249 (1946).

8 Joseph v. Carter \&: Weekes Stevedoring Co., 330 U.S. 422 (1947); Central Greyhound Lines, Inc. v. Mealey, 334 U.S. 653 (1948); Memphis Natural Gas Co. v. Stone, 335 U.S. 80 (1948).

9 Memphis Steam Laundry Cleaner, Inc. v. Stone, 342 U.S. 389 (1952); Miller Bros. v. Maryland, 347 U.S. 340 (1954); Railway Express Agency, Inc. v. Virginia, 347 U.S. 359 (1954).

10 Michigan-Wisconsin Pipe Line Co. v. Calvert, 347 U.S. 157, 166 (1954) (tax may not burden commerce "either directly or by the possibility of multiple taxation") .

11358 U.S. 450 (1959) (together with Williams v. Stockham Valves \& Fittings, Inc.). 
collector, ${ }^{12}$ denounced the result as "alarming," 13 "shocking," 14 and "a serious-if not fatal burden-to the small businessman," 15 and they sought protective federal legislation. ${ }^{16}$ Congress, responding sympathetically, took a mere seven months to enact a bill that narrowed the scope of state power to levy taxes imposed on or measured by the net income of interstate business. ${ }^{17} \mathrm{~A}$ host of observers, not all of them disinterested, ${ }^{18}$ contributed copiously to the

12 The concern, particularly of small businessmen, with the difficulties and costs of complying with the differing requirements of the tax laws of the numerous jurisdictions in which they may have carried on some interstate business was, at least according to their testimony, as great as their concern with whatever increased tax burden they might incur. See Hearings on State Taxation on Interstate Commerce Before the Senate Select Comm. on Small Business, 86th Cong., 1st Sess., pts. 1 \& 2 passim (1959) ; Hearings on S.J. Res. 113, S. 2213, S. 2281 Before the Senate Comm. on Finance, 86th Cong., 1st Sess. passim (1959).

The refusal of the Court to grant certiorari in International Shoe Co. v. Fontenot, 236 La. 279, 107 So.2d 640 (1958), cert. denied, 359 U.S. 984 (1959), appeared to sanction the extension of the principle of Northwestern, which involved taxpayers who maintained offices in the taxing state, to the situation in wbich the only in-state activity of the foreign corporation was solicitation of orders.

13 Hearings on S.J. Res. 113, S. 2213, S. 2281 Before the Senate Comm. on Finance, 86th Cong., lst Sess. 52 (1959) (statement of Benjamin O. Johnson, Chairman, Tax Committee, American Cotton Manufacturers Institute, and Chairman, Legislative Committee, National Fisheries Institute, Inc.).

14 Hearings on State Taxation on Interstate Commerce Before the Senate Select Comm. on Small Business, 86th Cong., 1st Sess., pt. 2, at 289 (1959) (statement of Jay L. Fialkow, Executive Director, Apparel Industries of New England).

15 Id., pt. 1, at 51 (statement of A.S. Thomas, Jr., President, Thomas Field \& Co., Charleston, W. Va.) .

16 See note 12 supra.

17 Act of Sept. 14, 1959, Pub. L. No. 86-272, § 101, 73 Stat. 555 (codified at 15 U.S.C. § $381(1970)$ ). The statute established a minimum threshold of intrastate activities which must be exceeded by an interstate corporation before tax liability of the kind sustained in Northwestern attaches. Specifically, the act precludes a state from imposing net income tax upon a business where the only in-state activity is soliciting orders or using independent contractors to make sales. A review of the legislative history, a sampling of early reactions, and some preliminary analysis may be found in Dane, Small Business Looks at Public Law 86-272 in the Perspective of Its Alternatives, 46 VA. L. REv. 1190 (1960); Roland, Public Law 86-272: Regulation or Raid, 46 VA. L. REv. 1172 (1960); Note, State Taxation of Interstate Commerce: Public Law 86-272, 46 VA. L. Rev. 297 (1960). For a recent study of the problems courts have encountered in interpreting this statutory provision, see Note, Public Law 86-272: Legislative Ambiguities and Judicial Difficulties, 27 VAND. L. Rev. 313 (1974).

18 See, e.g., Cox, Impact of the Stockham Decision, 37 TAxes 299 (1959) (the author, Director of the Georgia Department of Revenue's income tax unit, was "intimately connected" with the successful appeal of Stockham Valves, the companion case to Northwestern, in the Supreme Court); Maun, Stockham, Northwestern States, End Long Fight but Raises Numerous Business Problems, $10 \mathrm{~J}$. TAXATION 280 (1959) (the author argued 
legal literature,,$^{19}$ and some suggested that these developments heralded a new epoch in state taxation of interstate business. ${ }^{20}$

In light of the commotion spawned by Northwestern, developments in the field of state taxation of interstate business over the past 15 years may have been more modest than some had anticipated. While Congress produced an extensive and invaluable study of the problem ${ }^{21}$ and from time to time evinces an interest in legislating broadly in the area, ${ }^{22}$ it has nevertheless failed to act. Despite the strides the states have taken toward putting their own houses in order, ${ }^{23}$ their efforts are presently being strenuously resisted-

the case for the Northwestern States Portland Cement Company in the Supreme Court).

19 Northwestern and related developments were the focus of numerous individual pieces, e.g., Britton, Taxation Withoul Representation Modernized, 46 A.B.A.J. 369, 526 (1960); Silverstein, State Taxation of Interstale Commerce; A First Look at the "Net Income" Cases, 11 The TAX ExecuTrue 200 (1959); Note, State Taxation of Interstale Commerce: Constitutionality of Net Income Tax on Out-of-State Corporations, 12 VAND. L. REv. 904 (1959), as well as more extensive undertakings, e.g., Symposium-State Taxation of Interstate Commerce, 46 VA. L. REv. 1051 (1960); Developments in the LawFederal Limitations on State Taxation of Interstate Business, 75 HARv. L. REv. 953 (1962) [hereinafter cited as Developments]. See also authorities cited in notes 18 supra \& 20 infra.

20 See J. Hellerstein, An Academician's View of State Taxation of Interstate Commerce, I6 TAX L. Rev. 159 (1961); Note, Taxation-A New Era in Taxing Interstate Income, 11 West. Res. L. REv. 308, 313 (1960).

21 SPEcial. Subcomm. on State Taxation of Interstate Commerce of the House Comm. on the Judiciary, State Taxation of Interstate Commerce, H.R. Rep. No. 1480, 88th Cong., 2d Sess. (1964); H.R. REP. Nos. 565 and 952, 89th Cong., 1st Sess (1965) [paginated 1-1255, A1-A752, hereinafter cited as Willis Commitree REPORT]. Congress had directed this study in Act of Sept. 14, 1959, Pub. L. No. 86-272, $\$ 201,73$ Stat. 555, see note 17 supra, and subsequently broadened its scope, which initially embraced only state income taxes, to include taxes on capital stock, sales, use, and gross receipts. See Act of Apr. 7, 1961, Pub. L. No. 87-17, 75 Stat. 41; Act of Apr. 21, 1962, Pub. L. No. 87-435, 76 Stat. 55.

22 Congressional hearings on proposed legislation were held in 1966, Hearings on $H . R$. 11798 Before the Special Subcomm. on State Taxation of Interstate Commerce of the House Comm. on the Judiciary, 89th Cong., 2d Sess. (1966), and in 1973, Hearings Before the Subcomm. on State Taxation of Interstate Commerce of the Senate Finance Comm., 93d Cong., 1st Sess. (1973) . Bills were passed by the House in 1968, H.R. 2158, 90th Cong., 2d Sess. (1968), see 114 Cong. Rec. 14,432-33 (1968), and in 1969, H.R. 7906, 91st Cong., Ist Sess. (1969), see 115 CoNc. Rrc. 17,323 (1969), only to die in the Senate. For a discussion of recent legislative proposals, see Glaser, Proposed Solutions to Areas of Conflict in Taxation of Interstate Business, in I 33RD ANN. N.Y.U. INST. ON FED. TAXATTON 983 (1975) ; New York State Bar Ass'n Tax Section, Committee on Interstate Taxation, Proposals for Improvement of Interstate Taxation Bills, 25 TAX LAwYER 433 (1972) ; New York State Bar Ass'n Tax Section, Committee on Interstate Taxation, Supplemental Proposals for Improvement of Interstate Taxation Bills, 27 TAX LAWYER 213 (1974).

23 Under the shadow of federal restrictions on their taxing powers, the states have moved towards voluntary solution of a number of the problems raised by state taxation of 
and to a large extent stymied-by multistate businesses. ${ }^{24}$ Similarly, although it has issued some opinions of general significance, ${ }^{25}$ the Court has for the most part remained on the sidelines, ${ }^{26}$ perhaps in anticipation of congressional action. ${ }^{27}$

It was therefore an item of more than routine interest when the Supreme Court, late in the 1973 term, noted probable jurisdiction

interstate business. See Comment, State Taxation of Interstate Commerce: Roadway Express, the Diminishing Privilege Tax Immunity, and the Movement Toward Uniformity in Apportionment, 36 U. CHI. L. REv. 186, 211-12 (1968). "The principal vehicle has been the Multistate Tax Compact, which is subscribed to by over 35 states as either members or associate members. P-H State \& Local TAXes (All States Unit) II 5150-51 (1975). Among the key provisions are those giving the multistate taxpayer the option of apportioning and allocating his income with reference to the uniform criteria embodied in article IV of the compact, $i d$. $\{\Uparrow 6315-32$, and those providing for interstate audits under the auspices of the Multistate Tax Commission, id. Пโ 6342-50; see Cappetta, Joint Audit Program of the Multistate Tax Commission, in 1 33RD ANn. N.X.U. INsT. ON FEd. TAX.1TTON 961 (1975) See generally Note, State Taxation of Interstate Businesses and the Multistate Tax Compact: The Search for a Delicate Uniformity, 11 Colum. J. Law \& Soc. Probs. 231 (1975) .

24 See Dorgan v. International Business Machs. Corp., Civil Nos. A1-74-24 \& -25, P-H State \& Local TAXes (All States Unit) If 6621 (D.N.D., filed Oct. 24, 1974); United States Steel Corp. v. Multistate Tax Comm'n, P-H State \& Local TAxes (All States Unit) I 6619 (S.D.N.Y. 1974); United States Steel Corp. v. Multistate Tax Comm'n, 367 F. Supp. 107 (S.D.N.Y. 1973) ; Colgate-Palmolive Co. v. Durgan, 225 N.W.2d 278 (N.D. 1974) But see State Tax Comm'n v. Union Carbide Corp., 396 F. Supp. 250 (D. Idaho 1974); Kinnear v. Hertz Corp., P-H State \& Local Taxes (All States Unit) If623 (Wash. Super. Ct., filed Feb. 6, 1975). Some illuminating background to these disputes is detailed in Krol, Taxpayers Balking at Submitting to Audits of Multistate Tax Commission, 43 J. TAx. 364 (1975) .

25 Norfolk \& W. Ry. v. Missouri State Tax Comm'n, 390 U.S. 317 (1968); National Bellas Hess, Inc. v. Department of Revenue, 386 U.S. 753 (1967); General Motors Corp. v. Washington, 377 U.S. 436 (1964); Scripto, Inc. v. Carson, 362 U.S. 207 (1960) .

26 The most striking recent example of the Court's reluctance to become embroiled in controversies involving state taxation of interstate business was its refusal-despite the urgings of the Tax Executives Institute, Inc., the Financial Executives Institute, the National Association of Manufacturers, and the Committee on State Taxation of the Council of State Chambers of Commerce-to give plenary consideration to two state court decisions involving the Kennecott Copper Corporation. Chase Brass \& Copper Co. v. Franchise Tax Board, 10 Cal. App. 3d 496, 95 Cal. Rptr. 805, appeal dismissed, 400 U.S. 961 (1970); Kennecott Copper Corp. v. State Tax Comm'n, 27 Utah 2d 119, 493 P.2d 632, appeal dismissed, 409 U.S. 973 (1972). As a result of inconsistent determinations as to what constitutes a unitary business subject to apportionment on a combined or consolidated basis, Kennecott was "subjected to taxation on considerably more than 100 percent of its income." Hearings Before the Subcomm. on State Taxation of Interstate Commerce of the Senate Finance Comm., 93d Cong., 1st Sess. 80 (1973) (testimony of Senator Mathias). See also cases cited at notes 157-59 infra.

27 See National Bellas Hess, Inc. v. Department of Revenue, 386 U.S. 753, 760 n.15 (1967). 
in two cases raising issues of central importance with respect to state tax power over interstate business. Standard Pressed Steel Co. $v$. Department of Revenue ${ }^{28}$ presented critical questions concerning due process and commerce clause limitations on a state's power to impose an unapportioned gross receipts tax on an interstate vendor; Colonial Pipeline Co. v. Traigle ${ }^{29}$ posed the recurring and unresolved question of the scope and vitality of the doctrine that the "privilege" of doing interstate business is immune from state taxation. One might have thought that the Court, after hesitating to enter such controversies for a decade and a half, had at last decided to address these issues. But when the opinions came down, they were singularly unenlightening, and hopes for a renaissance in the Court's interest in the problem of state taxation of interstate business were proven false or at least premature. Moreover, the opinions raised serious questions about the Court's perception of its own role in this area.

My purpose here is three-fold: first, to analyze what the Court in fact did in Standard and Colonial; second, to examine in greater detail some of the issues that the decisions raised; and finally, to consider the broader significance of what the Court did not do.

\section{STANDARD PRESSED STEEL}

Standard Pressed Steel Co. v. Department of Revenue ${ }^{30}$ is the latest episode in the continuing saga of Washington's business and occupation tax in the Supreme Court. Since it was first enacted during the Depression to replenish dwindling state revenues, ${ }^{31}$ the tax, which is imposed on the act or privilege of engaging in business activities and measured by gross proceeds, gross income, or

28 10 Wash. App. 45, 516 P.2d 1043 (1973), prob. juris. noted, 417 U.S. 966 (1974).

29289 So. $2 d 93$ (La. 1974), prob. juris. noted, 417 U.S. 966 (1974). The United States Reports erroneously identifies the intermediate state appellate court's decision, 275 So.2d 834 (La. App., 1st Cir. 1973), as the one from which an appeal was taken.

After probable jurisdiction was noted, Joseph N. Traigle, who replaced E. Lee Agerton as Louisiana Collector of Revenue, was made the named appellee in the Supreme Court. The references in the text will be solely to Colonial Pipeline Co. $v$. Traigle to avoid confusion.

30419 U.S. 560 (1975).

31 See Gwin, White \& Prince, Inc. v. Henneford, 305 U.S. 434, 443 (1939) (Black, J., dissenting). 
product value ${ }^{32}$ has nine times been the subject of Supreme Court adjudication. ${ }^{33}$

\section{A. The Decision}

Standard Pressed Steel produced and sold industrial and aerospace fasteners-more readily identifiable as nuts and bolts. ${ }^{34}$ It was a Delaware corporation with manufacturing plants in Pennsylvania, where it maintained its home office, and in California. Standard made substantial sales of its products to the Boeing Company, which was its principal customer in Washington. ${ }^{35}$ The activities of Standard in the state of Washington derived exclusively from the duties performed there by the company's single resident employee and by its nonresident engineers, who visited the state for three days every six weeks. Standard maintained no inventory in the state, its sales dealings and negotiations were carried on directly

32 The general taxing provision reads:

There is levied and shall be collected from every person a tax for the act or privilege of engaging in business activities. Such tax shall be measured by the application of rates against value of products, gross proceeds of sales, or gross income of the business, as the case may be.

Wash. Rev. CODE ANN. $\$ 82.04 .220$ (1962). The statute then enumerates particular categories of taxpayers, specifying the appropriate measure to which the rate (generally $0.44 \%$ ) is applied, see note 150 infra: extractors (value of products extracted for sale or for commercial or industrial use), id. $\$ 82.04 .230$ (Supp. 1974); manufacturers (value of products manufactured), id. $\$ 82.04 .240$ (Supp. 1974); retailers (gross proceeds), id. $\S$ 82.04.250 (Supp. 1974); wholesalers and distributors (gross proceeds), id. $\$ 82.04 .270$ (Supp. 1974); and other businesses (gross income), id. $\$ 82.04 .290$ (Supp. 1974). The business and occupation tax is thus a series of excise taxes with varying bases that are gross in nature, although limited deductions are permitted. $I d$. $\$ 82.04 .430$ (Supp. 1974). See CCH Wash. State Tax Rep. $\$ 65,003$ (1974). See generally Comment, The Scope of Washington's Business and Occupation Tax, 35 WAsH. L. REv. 121 (1960).

33 Prior to Standard Pressed Steel, the Court had considered the tax in General Motors Corp. v. Washington, 377 U.S. 436 (1964); Field Enterprises, Inc. v. Washington, 352 U.S. 806 (1956) (per curiam) : General Elec. Co. v. Washington, 347 U.S. 909 (1951) (per curiam); Gwin, White \& Prince, Inc. v. Henneford, 305 U.S. 434 (1939); Rainier Nat'l Park Co. v. v. Martin, 302 U.S. 661 (1938) (per curiam); Silas Mason Co. v. Tax Comm'n, 302 U.S. 186 (1937); Puget Sound Stevedoring Co. v. State Tax Comm'n, 302 U.S. 90 (1937); and Fisher's Blend Station, Inc. v. State Tax Comm'n, 297 U.S. 650 (1936).

34 The ensuing description of the factual background of the case is drawn variously from the Supreme Court's opinion, 419 U.S. 560 (1975), the Washington Court of Appeals' opinion, 10 Wash. App. 45, 516 P.2d 1043 (1973), and the Washington Board of Tax Appeals' opinion, Dkt. No. 70-41 (May 26, 1971) [hereinafter cited as BTA], which present the facts in increasing detail.

35 Because Standard treated its other Washington customers similarly, the case was limited by agreement of counsel to Standard's treatment of Boeing as a çustomer. Appellee's Motion to Dismiss or Affirm at 17 n.l. But see note 37 infra. 
between its out-of-state offices and Boeing, it received orders directly from Boeing and filled them by shipping directly to Boeing through a common carrier, and it received payments directly from Boeing. While Standard maintained and was directly billed for a telephone answering service listed in its own name, messages from this service were relayed to the resident employee for response and action. $^{36}$

Standard's single employee permanently located in Washington during the period in question was Robert Martinson, an engineer whose primary responsibility was to consult with Boeing personnel regarding the company's anticipated needs for aerospace fasteners. ${ }^{37}$ Operating out of his own home, Martinson devoted most of his time to transmitting this information to Standard's out-of-state offices, where Standard would determine whether to seek to "qualify" as a Boeing supplier of a particular fastener. If such a determination were made and Standard's sample fasteners met the requisite specifications, thus enabling it to become an "approved source," Martinson would be "bypassed completely" 38 in the subsequent negotiations between Boeing and Standard's out-of-state offices concerning the purchase of the fasteners. Martinson also spent a small percentage of his time ascertaining any difficulties Boeing had experienced with Standard's products and relaying this information to Standard's out-of-state engineers. In addition, he arranged meetings between Boeing engineers and groups of

36 While both the Washington Board of Tax Appeals and the state in its brief in the Supreme Court noted that during the early part of the period in question Standard maintained its own sales office in Seattle, BTA 1; Brief for Appellee at 7, no mention of that fact is made in the opinion either of the Supreme Court or the state court of appeals, and it is presumably without decisional significance.

37 Despite the apparent similarity between Standard's relationship to Boeing and to its other Washington customers, see note 35 supra, the state contended that "Martinson confined his activities exclusively to representing Standard in its relation with Bocing, his superiors being of the view that other Washington customers did not generate enough business to make it worth his time." Brief for Appellee at 7-8. This would seem to be a rather damaging concession for the state to make insofar as it sought to tax Standard's receipts from its sales to Wasbington customers other than Boeing.

except to the extent that he periodically informed [Standard] of the various subcontractors, purchasing specialists, and control buyers of commodities for which [Standard] was an approved source . . . Martinson had nothing to do with quoting prices, delivery dates, receiving, soliciting, accepting orders, handling shipments or approving credit.

3s 10 Wash. App. at 48, 516 P.2d at 1046. As the court explained, Id. 
Standard's visiting engineers to supplement his own efforts and to discuss engineering problems.

The findings of the Board of Tax Appeals, repeated in substance by the Supreme Court, ${ }^{39}$ were that Martinson's activities enabled Standard to:

1. Become aware of its products which The Boeing Company might be able to use.

2. Obtain the engineering design for such products.

3. Secure the testing of sample products to qualify the products for sale to The Boeing Company.

4. Resolve problems in the use of the products after receipt and use by The Boeing Company.

5. Obtain and retain good will and working rapport with Boeing personnel.

6. Secure and update lists of Boeing purchasing specialists or control buyers, and the commodities for which they were responsible, for the use of the invoicing personnel at the appellant's home office. ${ }^{40}$

On the basis of these activities, the state Department of Revenue assessed its business and occupation tax against Standard as applied to the unapportioned gross receipts resulting from its sales to Boeing. ${ }^{41}$ Three Washington tribunals-the Board of Tax Appeals, the Thurston County Superior Court, and the Court of Appealssustained the Department's assessment, and the state supreme court denied review. ${ }^{42}$

39419 U.S. at 561 .

40 BTA at 3.

11 W ASH. REV. CoDE ANN. \$ 82.01 .220 (1962). Standard was taxed under the "wholesaler" provisions of Washington's business and occupation tax, see note 32 supra, which read in pertinent part during the period here at issue (January 1,1965 , to June 30, 1969, see $\mathrm{BTA}$ I) :

Upon every person . . engaging within this state in the business of making sales at wholesale .. . the amount of tax with respect to such business shall be equal to the gross proceeds of sales of such business multiplied by the rate of one-quarter of one percent.

Wash. REv. Code ANN. $\$ 82.04 .270$ (1962). The rate has since been increased to $0.44 \%$. Id. $\$ \$ 2.01 .270$ (Supp. 1974) .

42 The only one of these opinions officially reported is that of the Washington Court of Appeals. 10 Wash. App. 45, 516 P.2d 1043 (1973). The oral opinion of the Thurston County Superior Court is reproduced as Appendix A to appellant's jurisdictional statement. See also note 34 supra. 
In a brief opinion, the United States Supreme Court unanimously affirmed..$^{43}$ The Court posed the due process issue as whether the "in-state activities were so thin and inconsequential as to make the tax on activities occurring beyond the borders of the State one which has no reasonable relation to the protection and benefits conferred by the taxing State." ${ }^{44}$ It thus collapsed into a single question two separate inquiries: (1) whether the tax was in fact imposed on out-of-state activities and (2) whether the tax was reasonably related to protection and benefits conferred by the taxing state. ${ }^{45}$ The Court failed to address even its own question and instead restated the issue in the classic but imprecise formulation of Wisconsin v.J.C. Penney Co.: ${ }^{40}$ "whether the State has given anything for which it can ask return." 47 It then offered the conclusory response that "the question in the context of the present case verges on the frivolous," 48 citing the fact that Martinson "made possible the realization and continuance of valuable contractual relations between [Standard] and Boeing." "49 The Court thereby finessed the important question whether the in-state activity in which Martinson engaged was fairly measured by the unapportioned gross receipts of Standard's sales to Boeing-a consideration neither the parties ${ }^{50}$ nor the court below ${ }^{51}$ had had the temerity to ignore.

43419 U.S. 560 (1975).

44 Id. at 562 .

45 The Court appears at this point in its opinion to be assuming that the tax is imposed "on activities occurring beyond the borders of the State," although perhaps it is simply stating what it deems appellant's argument to be. If it is not, its statement is inconsistent with the final paragraph of its opinion, which states that the "activities taxed" are "intrastate." Id. at 564 .

46311 U.S. $435(1910)$.

47419 U.S. at 562, quoting Wisconsin v. J.C. Penney Co., 311 U.S. 435, 444 (1940).

48419 U.S. at 562 .

49 Id.

50 Brief for Appellant at 23-24; Brief for Appeltee at 29-30.

51 As the Washington Court of Appeals stated, after concluding that Martinson's activities constituted a "sufficient peculiarly local and distinct taxable incident within the State of Washington," 10 Wash. App. at 50, 516 P.2d at 1046:

Our inquiry does not end here, however, for even when there is a peculiarly local activity, the measure of the tax must be reasonably related to those local incidents. General Motors Corp. v. Washington, supra. A tax measured by gross receipts from sales by a foreign corporation to customers within the state must be closely related to the local activities of the corporation, for due process requires "some definite link, 
The Court's treatment of the commerce clause questions ${ }^{52}$ began with the mysterious remark that " $[t]$ he case is argued on the interstate commerce aspect as if Washington were taxing the privilege of doing an interstate business with only orders being sent from within the State and filled outside the State. . . " ${ }^{53}$ It never bothered to explain whether it rejected that characterization, which it presumably did, ${ }^{54}$ and if so, why, since it is clear from its statement a few paragraphs earlier that orders were indeed "sent from within the State and filled outside the State." 55 The Court disposed of Norton Co. v. Department of Revenue," which had held certain interstate sales nontaxable under Illinois' gross receipts tax, as involving little more than the taxpayer's ability to carry the burden of establishing its immunity by showing the lack of a nexus between its local office and the interstate sales. ${ }^{57}$ It did not mention the much more substantial activities carried on by Norton in Illinois than by Standard in Washington. ${ }^{58}$ And it characterized General Motors Corp. v. Washington, ${ }^{59}$ which involved the same tax provisions at issue in Standard, as "almost precisely in point so far as the present controversy goes." ${ }^{60}$ Yet the Court's own statement of the facts of General Motors belied the accuracy of its purported analogy. ${ }^{\text {B1 }}$

some minimum connection, between a state and the person, property or transaction it seeks to tax."

Id., 516 P.2d at 1046-47 (citation omitted) .

52 In some respects, these are inseparable from the due process questions. See National Bellas Hess, Inc. v. Department of Revenue, 386 U.S. 753, 756 (1967); International Harvester Co. v. Department of Treasury, 322 U.S. 340, 353-56 (1944) (Rutledgc, J., concurring); Hartman, State Taxation of Interstate Commerce: $A$ Survey and an Appraisal, 46 VA. L. REv. 1051, 1058-65 (1960).

53419 U.S. at 562 (emphasis supplied).

54 "Of course, no State can tax the privilege of doing interstate business." General Trading Co. v. State Tax Comm'n, 322 U.S. 335, 338 (1944). See generally part II infra.

55 "Martinson did not take orders from Boeing; they were sent directly to appellant [outside the State]. Orders accepted would be filled and shipment made by common carrier to Boeing direct. . . " 419 U.S. at 561 .

66340 U.S. 534 (1951).

57419 U.S. at 563.

58 See text at notes 67-76 infra.

50377 U.S. 436 (1964) - See text at notes 83-88 infra.

60419 U.S. at 563.

61 While the zone manager for sales of the Chevrolet. Pontiac, and Oldsmobile divisions was in Portland, Ore., district managers lived and operated within Washington. Each operated from his home, having no separate office. Each had from 12 to 30 dealers under supervision. He called on each of these dealers, kept tabs on the sales 
Finally, after noting that the taxpayer had failed to demonstrate that imposition of Washington's tax would subject it to multiple taxation, the Court ended its opinion with the puzzling comment that the tax "is 'apportioned exactly to the activities taxed,' all of which are intrastate." ${ }^{62}$ This disposed of the entire apportionment issue in a single cryptic phrase, yet left unanswered the question how an "unapportioned" tax on gross receipts can be "apportioned exactly" to activities which were only partially responsible for their creation. ${ }^{63}$

\section{B. The Nexus Perplex}

Among the key issues raised by Standard Pressed Steel was whether the imposition of Washington's gross receipts levy upon Standard was consistent with the due process requirement that there be "some definite link, some minimum connection, between a state and the person, property or transaction it seeks to tax." ${ }^{64}$ The Court referred to this "nexus" issue ${ }^{65}$ in its discussion of the Norton case, adverting to "the burden of showing a nexus between the local office and interstate sales-whether a nexus could be assumed and whether the taxpayer had carried the burden of establishing its immunity." "6 But it did not pause to consider how this requirement applied to the facts in Standard, an omission that becomes readily understandable when we measure the distance the Court has traveled since Norton.

Norton Co. v. Department of Revenue ${ }^{67}$ is the seminal decision in a line of cases that have raised perplexing nexus issues in

forces, and advised as to promotional and training plans. He also advised on used car inventory control. He worked out with the dealer estimated needs over a 30-, 60-, and 90-day projection of orders. General Motors also had in Washington service representatives who called on dealers regularly, assisted in any troubles experienced, and checked the adcquacy of the service department's inventory. They conducted service clinics, teaching dealers and employees efficient service techniques. 419 U.S. at 563 . The Court in General Motors had described this as constituting "a substantial local business" and "a maze of local connections." 377 U.S. at 439, 448.

62419 U.S. at 564 (citation omitted).

63 See text at notes 98-117 infra.

64 Miller Bros. v. Maryland, 347 U.S. 340. 344-45 (1954).

65 While the Court in Miller Bros. did not actually employ the term "nexus," the Court has subsequently used this word to characterize the requirement. See American Oil Co. v. Neill, 380 U.S. 451, 458 (1965) : Scripto, Inc. v. Carson, 362 U.S. 207, 210-11 (1960); Northwestern States Portland Cement Co. v. Minnesota, 358 U.S. 450, 464.65 (1959).

66419 U.S. at 563 .

67340 U.S. 534 (1951). 
connection with the application of a state's unapportioned gross receipts tax to an out-of-state vendor making sales to in-state customers. The unapportioned character of the levies has forced the Court to fashion its own mechanism for determining whether state tax power has been exerted solely over receipts that arise from the taxpayer's activities within the taxing state. ${ }^{68}$ This may suggest that we are actually dealing with an apportionment question masquerading as a nexus question, a possibility that is addressed below. ${ }^{69}$ The Court, however, has approached the issue as a nexus question, and lawyers will consequently continue to address it as such; it may therefore be useful to examine the issue in these terms despite the possibility that more appropriate analytical approaches exist.

Norton involved an Illinois tax imposed "upon persons engaged in the business of selling tangible personal property at retail" 70 and measured by the gross receipts of the business. The taxpayer was a Massachusetts manufacturer and vendor of abrasive machines and supplies with a branch office and warehouse in Chicago from which it made local sales. Illinois assessed its levy upon the gross receipts of all of Norton's sales to Illinois customers, which included sales resulting from

(1) Direct over-the-counter purchases at the Chicago office;

(2) Orders filled in Massachusetts but received by and/or shipped via the Chicago office; and

(3) Orders sent directly to Massachusetts and filled by direct shipment to Illinois customers.

The Court initially noted that "[u]nless some local incident occurs sufficient to bring the transaction within its taxing power, the vendor is not taxable." "I Since Norton had satisfied this test by having "gone into the State to do local business," 72 the Court

68 Compare the fairly apportioned tax at issue in Northwestern States Portland Cement Co. v. Minnesota, 358 U.S. 450, 464 (1959) (citation omitted):

The taxes imposed are levied only on that portion of the taxpayer's net income which arises from its activities within the taxing State. These activities form a sufficient "nexus between such a tax and transactions within a state for which the tax is an exaction."

69 See text at notes $97-136$ infra.

70 ILL. REv. STAT. ch. 120, § 441 (1949), quoted at 340 U.S. 535.

71340 U.S. at 537.

72 Id. 
next confronted the question whether Norton's local activity was sufficiently related to the assertion of state tax power to justify the exaction. First, it laid down the basic evidentiary rule that all the sales at issue were presumed to be related to the local activity; "only by showing that particular transactions are dissociated from the local business and interstate in nature" 73 can a taxpayer rebut this presumption and avoid taxation on such transactions. Turning to the facts, the Court held that the Illinois court's judgment "attributing to the Chicago branch income from all sales that utilized it either in receiving orders or distributing the goods was ... permissible," "74 since the taxpayer-and here the Court fleshed out its "dissociation" test-had "not established that the services rendered by the Chicago office were not decisive factors in establishing and holding this market" and "no other source of customer relationship [had been] shown." " 5 Hence sales in categories (1) and (2) above gave rise to taxable receipts. As to category (3), however, the Court declared that these sales were "so clearly interstate in character that the State could not reasonably attribute their proceeds to the local business," 76 and they were therefore nontaxable.

Norton seemed to establish reasonably concrete and comprehensible criteria for determining an out-of-state vendor's exposure to gross receipts tax liability. But in Field Enterprises, Inc. $v$. Washington ${ }^{77}$ the next case in this line, the Norton construct began to show some strain. Field, a Delaware corporation with its principal place of business in Illinois, maintained a substantial sales force in the state of Washington to market two sets of its books. Field's Washington sales force of some 175 Washington residents was supervised and trained by a local sales office that also processed orders and down payments for transmittal to Illinois, handled local promotions, and secured credit investigations. In contrast to Norton, where the purely local aspects of the taxpayer's business generated some admittedly taxable sales, all the orders in Field Enterprises were accepted by the taxpayer's out-of-state office, and there was thus no purely local transaction upon which

73 Id.

74 Id. at 538.

75 Id.

$76 \mathrm{Id}$. at 539 .

77352 U.S. 806 (1956), aff'g per curiam 47 Wash. 2d 852, 289 P.2d 1010 (1955) . 
state tax power could be grounded. The Washington Supreme Court, relying principally upon an earlier decision of its own,$^{78}$ did not cite Norton but unmistakably referred to its language ${ }^{79}$ in declaring:

In the instant case, it cannot be denied that the services rendered by the taxpayer's Seattle office are decisive factors in establishing and holding the market in this state for its publications. ${ }^{80}$

The Supreme Court got the hint. Its entire opinion reads:

The judgment is affirmed. Norton Company v. Department of Revenue, 340 U.S. 534. Mr. Justice FrankfurTer and Mr. Justice HarLAN are of the opinion that probable jurisdiction should be noted. ${ }^{81}$

Field Enterprises thus left unclear the extent to which the existence of some "distinctly local" business remained a necessary predicate for the imposition of a gross receipts tax upon an out-of-state vendor. ${ }^{82}$

If the waters were slightly muddied after Field Enterprises, it required a major dredging operation to clean them up after General Motors Corp. v. Washington. ${ }^{83}$ At issue was Washington's business and occupation tax as applied to an out-of-state wholesaler and measured by the unapportioned gross receipts from sales of motor vehicles, parts, and accessories delivered in the state. General Motors' activities in Washington were extensive: it engaged in promotional and supervisory work through its local employees to foster sales and preserve the quality of its dealer organization, it maintained a warehouse from which some parts and accessories were sold to local dealers, and it had a local branch office which assisted Washington dealers in getting better service on their orders. General Motors conceded the taxability of receipts from sales made by its local warehouse but contested the state's power to tax receipts from sales of items shipped from its out-of-

78 B.F. Goodrich Co. v. State, 38 Wash. 2d 663, 231 P.2d 325, cert. denied, 342 U.S. 876 (1951) .

79 Strecker, supra note 3 , at 74 .

8047 Wash. 2d at 856, 289 P.2d at 1012.

81352 U.S. 806 (1956).

82 See Strecker, supra note 3, at 74; cf. W. Beaman, Paying Taxes to Other States $12-18$ (1963).

83377 U.S. 436 (1964). 
state offices to in-state dealers in response to orders sent by the dealers to these offices.

In addressing the status of the disputed receipts, the Court appeared to reiterate the Norton rule but with an odd twist. Whereas in Norton it had stated that once the taxpayer had come into the state to do local business, it could avoid taxation "only by showing that particular transactions are dissociated from the local business and interstate in nature," 84 in General Motors it stated that the taxpayer had "the burden of showing that the operations of these [General Motors] divisions in the State 'are dissociated from the local business and interstate in nature." "85 Any hope that this slippage might have been inadvertent was dashed when the Court turned to specifics. No longer was the sufficiency of the relationship between local activity and a gross receipts levy on an out-of-state vendor to be tested by the manageable criterion of whether the transactions producing the receipts were "associated" with such activity. For this the Court substituted a metaphysical "test": whether "the bundle of corporate activity ... [was] so enmeshed in local connections" 86 as to form a sufficient basis for the levy. By inquiring whether the aggregate of corporate activity giving rise to disputed sales had sufficient local connections, ${ }^{87}$ the Court abandoned a nexus standard requiring that taxable receipts emanate from transactions with a tangible and demonstrable link to local activities. It thereby created the possibility that the shapeless criterion of a locally "enmeshed" "bundle of corporate activity" would be used as a rhetorical device to sweep into the state tax collector's grasp all of a taxpayer's gross receipts from sales to instate customers. ${ }^{88}$

84340 U.S. at 537 (emphasis supplied).

85377 U.S. at 441 (emphasis supplied).

$88 \mathrm{Id}$. at 447.

87 The Supreme Court, 1963 Term, 78 HARv. L. REv. I43, 243 (1964).

88 See Barnes, State Taxation of Interstate Commerce: Chaos and New Hope, 16 West. REs. L. REv. 859, 868-71 (1965).

Less than a year after General Motors the Court handed down a decision indicating that the nexus requirement still had a role to play in limiting tive power of a state to tax sales made by out-of-state vendors. American Oil Co. v. Neill, 380 U.S. 451 (1965). At issue was an Idaho excise tax levied, inter alia, on the "receipt" by licensed dealers of motor fuels within the state. The petitioner, a Delaware corporation and a licensed dealer in Idaho, had effected a sale of gasoline for eventual use in Idaho through delivery to the federal government in Utah on the basis of a bid it had submitted there, in response to the government's invitation therefor and acceptance thereof in the state of Washington. The 
In effect, this taxpayer's nightmare came true in Standard Pressed Steel. Standard's in-state activities amounted only to those attributable to its single resident employee and the group of nonresident engineers who visited the State for some 25 days per year. None of Standard's local activity was directly involved with the transactions which gave rise to the receipts Washington sought to tax; orders, shipments, negotiations, and payments were all handled between Boeing and Standard's out-of-state offices. ${ }^{89}$ The Court, however, concluded that Martinson's critical role in making “possible the realization and continuance of valuable contractual relations between appellant and Boeing" ${ }^{90}$ created a sufficient link between Standard's in-state activities and its Washington sales to justify a tax upon all of them.

If General Motors blurred the nature of the requisite relationship between the local activity and the interstate transaction, Standard Pressed Steel carried this process one step further by employing a nexus criterion that freed the local activity from the specifics of the transaction generating the allegedly taxable receipts. While General Motors suggested that the Court was taking a more relaxed view of the necessity of matching local activity to interstate sales on a transaction-by-transaction basis, this view seemed to be predicated on the existence of General Motors' "substantial local business" ${ }^{91}$ and its "maze of local connections." 92 These placed the state court's decision "within the realm of permissible

state had prevailed below on the grounds that the sales transaction in question amounted to a "receipt" by the Idaho dealer within the purview of Idaho's taxing power because the company knew the fucl would be imported into and used in Idaho and because it had been authorized to do business in the state. The Supreme Court reversed. It admitted that there is a strong inference that, once a corporation "pursuant to permission given, enters a State and proceeds to do local business," id. at 458, the requisite nexus "exists hetween the State and transactions which result in economic benefits obtained from a source within the State's territorial limits." Id. But it went on to point out that the corporation "can . . . exempt itself by a clear showing that there are no in-state activities connected with out-of-state sales," which it had done since its "transfer of gasoline was unquestionably an out-of-state sale vis-a-vis Idaho and entirely unconnected with its business in that State." Id.

89 Indeed, the state conceded that " . . . in-state activities pertaining to claimed exempt wholesale transactions were not directly related to obtaining and processing orders." Brief for Appellee at 38.

90419 U.S. at 562.

91377 U.S. at 439.

92 Id. at 448. 
judgment" ${ }^{33}$ - a recognition, perhaps, by the Court that it would be impossible or impractical to make more refined determinations under such circumstances.

But in Standard there was nothing substantial or maze-like about the taxpayer's local activities. Rather, it was their critical nature that the Court relied upon in upholding the levy. By making it clear that qualitative as well as quantitative aspects of local activity not shown to be directly involved with interstate sales transactions affect the constitutionally permissible scope of a state's unapportioned gross receipts tax, ${ }^{94}$ the Court seems to have liberated the states completely from the restraints of Norton. Whether one looks to the enmeshed-bundle-of-corporate-activity standard or the making-contractual-relations-possible standard, the departure from the concrete criterion of Norton that the Court purported to embrace-the demonstration of "a nexus between the local office and interstate sales" ${ }^{95}$-is plain.

In sum, the force of the nexus limitation, employed over the years by the Court as an inhibition on state taxing power, has been eroded-at least in the area of gross receipts taxation-as the principles underlying it have become mired in conceptual quicksand. While the multistate business may appear to be the victim of these developments, recent history suggests that the business community is capable of inducing "corrective" action when sufficiently disturbed..$^{96}$

93 Id., quoting Norton Co. v. Department of Revenue, 340 U.S. 534, 538 (1951).

84 Understandably concerned with the sparseness of Standard's in-state activity in relation to the exercise of state tax power over Standard's sales, Washington had argued for the adoption of such a standard:

These due process requirements are qualitative and not quantitative. . . While differing as to detail and quantity, Martinson's in-state activities and that of visiting personnel are not qualitatively distinguishable from the activities of General Motors in regard to the wholesale sales at issue. . .

Brief for Appellee at 16-17.

05419 U.S. at 563.

96 See note 17 supra. It is unclear at this point whether there is cause for such concern. The first two reported opinions to consider the Court's decision in Standard reached opposite conclusions on the nexus issue. A Pennsylvania court relied on Standard to uphold the imposition of the state's corporate income tax on a corporation doing business in the state solely through its "missionary representatives" on the ground that "their presence made possible the realization and continuance of valuable contractual relations . . .." United States Tobacco Co. v. Commonwealth, _- Pa. Cmwlth. $-, \longrightarrow, 348$ A.2d 755, 760 (1975) (emphasis in original). By contrast, a California court had no trouble distinguishing Standard on the ground that "[v]ery definitely, Standard's agent Martinson was directly connected with the sale of its product to Boeing," whereas "[i]n our case the [tax- 


\section{Finessing the Apportionment Issue}

The unsatisfactory disposition of the nexus question in Standard Pressed Steel may represent an unsuccessful attempt by the Court to solve an apportionment problem with analytical tools illsuited to the task. For the determination whether a critical relationship exists between local activity and assertion of state tax power may be no more than a crude way of identifying the constitutionally appropriate tax base. Yet the search for such a tax base has traditionally been viewed as an apportionment rather than a nexus question. When dealing with property, income, and capital stock taxes, the states have historically relied on apportionment formulas to divide the tax base of an interstate enterprise equitably among those jurisdictions having a legitimate claim to part of that base. ${ }^{97}$

This historical pattern might logically have suggested a solution to the problem raised by the gross receipts tax at issue in Standard Pressed Steel, in light of the inadequacy of the nexus analysis in this regard as well as the Court's insistence over the years that proper apportionment is one of the constitutional touchstones in determining the validity of a gross receipts tax on interstate operations. ${ }^{98}$ Nevertheless, the Court barely touched on the apportionment question. It noted that the Washington levy was unapportioned; ${ }^{99}$ it quoted a paragraph from an earlier opinion that referred to the fact that "the tax, measured by the entire volume of the interstate commerce in which [the taxpayer] participates, is not apportioned to its activities within the state"; 100 and it "analyzed" the issue in two sentences:

payer's] agents in California had no connection with the sale of its products." National Geographic Soc'y v. Board of Equalization, 121 Cal. Rptr. 77, 84 (Cal. App.), hearing granted (Sup. Ct. 1975).

97 See W. Beaman, supra note 82 , at 3-1 to -21; P. Hartman, supra note 3, at 84-92, 238-46; Willis CoMmitTEE REPoRT, supra note 21, at 113. There are other methods of determining the portion of a tax base that may appropriately be attributed to a particular jurisdiction, see, e.g., W. BEAMan at 3-1 to -6 , but these are neither as widely used nor as universally applicable as apportionment formulas. See Comment, supra note 23, at 207-08 n.108.

98 See, e.g., Western Live Stock v. Bureau of Revenue, 303 U.S. 250, 256 (1938) ; Central Greyhound Lines, Inc. v. Mealey, 334 U.S. 653, 663 (1948); General Motors Corp. v. Washington, 377 U.S. 436, 440 (1964); Evco v. Jones, 409 U.S. 91,93 (1972).

99419 U.S. at 562 .

100 Id. at 564, quoting Gwin, White \& Prince, Inc. v. Henneford, 305 U.S. 434, 439 (1939) . 
In the instant case, as in Ficklen $v$. Shelby County Taxing District, 145 U.S. I (1892), the tax is on the gross receipts from sales made to a local consumer, which may have some impact on commerce. Yet as we said in Gwin, White of Prince, supra, at 440, in describing the tax in Ficklen, it is "apportioned exactly to the activities taxed," all of which are intrastate.101

The Court's reliance on Ficklen, which neither party cited in its briefs, was misplaced. Ficklen involved a Tennessee tax levied upon the "gross yearly commissions, charges, or compensations"102 of those engaged in the brokerage business. The taxpayers were general merchandise brokers domiciled in Tennessee, whose commissions derived entirely or substantially from orders solicited from local customers and sent to out-of-state vendors, who filled the orders by shipping the goods directly to the purchaser. In sustaining the levy over commerce clause objections, the Court stated:

[W]here a resident citizen engages in general business subject to a particular tax the fact the business done chances to consist, for the time being, wholly or partially in negotiating sales between resident and non-resident merchants, of goods situated in another State, does not necessarily involve the taxation of interstate commerce, forbidden by the Constitution.103

Fairly read, Ficklen might well stand as authority for taxing Martinson upon commissions paid to him on the basis of Standard's sales to Washington's customers. To suggest that it further stands as authority for taxing Standard upon receipts from such sales is a logical leap of some distance. For it assumes that the presence of a Martinson in the taxing state eliminates the distinction, for purposes of gross receipts taxation, between local brokerage activity and interstate sales activity. Although the line between these two classes of activity may sometimes be thin, there is nevertheless a "distinction between the sedentary and therefore more localized characteristics of brokerage and the boundary-straddling aspect of interstate sales." 104

101419 U.S. at 564 (footnote omitted).

102145 U.S. 1,4 (1892) .

$103 \mathrm{Id}$. at 21.

104 Powell, More Ado About Gross Receipts Taxes, 60 Harv. L. Rev. 501, 507 (1947). 
This distinction does not disappear simply by reference to $G w i n$, White's gloss on Ficklen. The tax in Ficklen was plainly "unapportioned" in the sense that the tax base was not divided by some method attributing a proportionate share of the taxpayer's gross receipts to the taxing state. ${ }^{105}$ By characterizing the tax as "apportioned exactly to the activities taxed, all of which were intrastate," ${ }^{106}$ the Gwin, White Court presumably meant that the tax in Ficklen was effectively measured by gross receipts of brokers' commissions that were generated by intrastate activities, namely the brokers' solicitation of sales from local customers. But to characterize the tax in Standard as similarly "apportioned" to " 'activities taxed,' all of which are intrastate," 107 is another matter. The only intrastate activities carried on by Standard in Washington were those of Martinson and Standard's visiting engineers. Thus, the premise underlying the justification for imposing an unapportioned gross receipts tax on Standard-that its intrastate activities were related to receipts Washington sought to tax as the brokers' intrastate activities in Ficklen were related to commissions Tennessee sought to tax-has no support in fact.

If this factual disparity were the function only of judicial carelessness or uncertainty regarding the definition of a properly "apportioned" gross receipts tax, careful analysis of the relevant precedents might clarify the issue. The problem, however, is more fundamental. There is a doctrinal disparity in the Court's treatment of the apportionment issue in Standard Pressed Steel. Despite its insistence that taxes measured by gross receipts from interstate commerce must be "fairly apportioned to the commerce carried on within the taxing state," 108 the Court has nevertheless sustained unapportioned taxes on the gross receipts from interstate sales. ${ }^{108}$

105 While commentators have routinely described the tax in Ficklen as "apportioned," see W. BEAMAN, supra note 82 , at 2-6; P. HARTMAN, supra note 3 , at $185 \mathrm{n.16}$; but see Dunham, supra note 3, at 221, perhaps in reliance on the Court's statement in Gwin, White, it is apparent froin exanining the statute, 145 U.S. at 4, as well as the opinion, that the tax was not by its terms apportioned.

106305 U.S. 434,440 (1939).

107419 U.S. at 564 .

108 Western Live Stock v. Bureau of Revenue, 303 U.S. 250, 256 (1938). See note 98 supra.

108 See, e.g., Field Enterprises, Inc. v. Washington, 352 U.S. 806 (1956), affg per curiam 47 Wash. 2d 852, 289 P.2d 1010 (1955); International Harvester Co. v. Department of Treasury, 322 U.S. 340 (1944). 
Of course, it would make analytic nonsense to talk about a "fairly apportioned" "unapportioned" tax if the concept of "apportionment" were intended to have any real meaning here. 110 Instead, what seems to have happened in cases like Standard is that the Court, while paying lip service to the apportionment principle, ${ }^{111}$ has ignored it in fact and has looked to other factors to determine the constitutionality of taxes imposed on the unapportioned gross receipts from interstate sales activity. ${ }^{112}$ Notwithstanding doctrinal variations, ${ }^{113}$ and assuming that nexus requirements have been satisfied, ${ }^{114}$ over the past four decades gross receipts taxes on interstate sales have generally been sustained when imposed by the state to which the goods were shipped ${ }^{115}$ and prohibited when imposed by the state from which the goods were sent. ${ }^{116}$

While Standard Pressed Steel thus falls within a class of unapportioned gross receipts levies the Court has sustained, it leaves at least two questions unanswered. First, why has the Court strayed from the apportionment principle in judging the constitutionality of gross receipts taxes on interstate sales activity? And, second, is this anomaly justified?

The answer to the first question would seem to lie in the fact that the Court, when dealing with levies measured by receipts from interstate sales, has analogized gross receipts taxes to retail sales

110 Indeed, T.R. Powell was of the opinion that gross receipts taxes on interstate sales were not susceptible to fair apportionment by formula. Powell, supra note 104, at 743; cf. W. BEAMAN, supra note 82, at 10-1. But see text at notes 117-29 infra.

111 See General Motors Corp. v. Washington, 377 U.S. 436, 440 (1964); Department of Treasury v. Wood Preserving Corp., 313 U.S. 62, 67 (1941).

112 See Dunham, supra note 3, at 225.

113 Compare, e.g., Gwin, White \& Prince, Inc. v. Henneford, 305 U.S. 434 (1939), with Freeman v. Hewit, 329 U.S. 249 (1946).

114 See text at notes 64-96 supra.

116 General Motors Corp. v. Washington, 377 U.S. 436 (1964) ; Field Enterprises, Inc. v. Washington, 352 U.S. 806 (1956), aff'g per curiam 47 Wash. 2d 852, 289 P.2d 1010 (1955); International Harvester Co. v. Department of Treasury, 322 U.S. 340 (1944); Department of Treasury v. Allied Mills, Inc., 318 U.S. 740 (1943), aff'g per curiam 220 Ind. 340, 42 N.E.2d 34 (1942); Wilurs COMMITTEE REPORT, supra note 21, at 1046, 1047; Strecker, supra note 3 , at 75 .

116 Evco v. Jones, 409 U.S. 91 (1972); Gwin, White \& Prince, Inc. v. Henneford, 305 U.S. 434 (1939) ; J.D. Adams Mfg. Co. v. Storen, 304 U.S. 307 (1938) ; see Willis CommitreE REPORT, supra note 21, at 1040, 1047; cf. Freeman v. Hewit, 329 U.S. 249 (1946) . But see International Harvester Co. v. Department of Treasury, 322 U.S. 340 (1944) (exception when out-of-state purchaser accepts delivery in taxing state, "class D sales"). 
and use taxes. ${ }^{117}$ Because retail sales and use taxes are consumer taxes which are separately stated, collected from the purchasers, and imposed on a transaction-by-transaction basis, apportionment of such levies has never been viewed as a practicable solution to the commerce clause problems that such taxes raise. ${ }^{118}$ Instead, the Court in effect has had to decide whether the state from which the goods were sent, the state to which the goods were shipped, or both, or neither would be permitted to tax retail interstate sales. ${ }^{119}$ As the preceding discussion suggests, the Court has tended to allow the state of destination to tax such transactions while forbidding the state of origin from doing so. The application of what is essentially a single constitutional doctrine relating to the taxability of receipts from interstate sales may thus explain the deviation from the apportionment principle in cases involving gross receipts taxes on interstate sales.

The question remains, however, whether the deviation is warranted. In cases such as Norton, which involve consumer-type gross receipts taxes on interstate sales, ${ }^{120}$ considerations of practicality

117 The high-water mark for the conscious adoption of this approach was probably Justice Douglas' opinion for the Court in International Harvester Co. v. Department of Treasury, 322 U.S. 340 (1944), involving the application of Indiana's gross income tax to receipts from three categories of sales transactions:

In light of our recent decisions it could hardly be held that Indiana lacked constitutional authority to impose a sales tax or a use tax on these transactions. But if that is true, a constitutional difference is not apparent when a "gross receipts" tax is utilized instead.

Id. at 348. Although the strict equivalence between sales, use, and gross receipts taxes has not been maintained, see, e.g., Norton Co. v. Department of Revenue, 340 US. 534 (195I) (more substantial "local incidents" required for imposition of gross receipts than for sales or use tax); Willis Commitree ReporT, supra note 21, at 1044; Developments, supra note 19, at 1022-23, the Court has continued to view gross receipts taxes on interstate sales as transaction taxes rather than as general doing-business taxes. Standard Pressed Steel v. Department of Revenue, 419 U.S. 560 (1975); General Motors Corp. v. Washington, 377 U.S. 436 (1964).

118 Barrett, "Substance" vs. "Form" in the Application of the Commerce Clause to State Taxation, 101 U. PA. L. REv. 740, 755, 776 (1953); Kust \& Sale, State Taxation of Interstate Sales, 46 VA. L. REv, 1290, 1323-24 (1960).

118 See International Harvester Co. v. Department of Treasury, 322 U.S. 340, 358.62 (1944) (Rutledge, J., concurring and dissenting).

120 Examples are New York City's sales tax, now L.L. 73, Laws 1965, as amended, §§ A46-1.0 et seq., reprinted in CCH N.Y. STATE TAX REP. ITT 190-801 et seq. (1975), which was considered in McGoldrick v. Felt \& Tarrant Mfg. Co., 309 U.S. 70 (1940), and McGoldrick v. Berwind-White Coal Mining Co., 309 U.S. 33 (1940); and Arkansas' gross receipts tax, ARK. STAT. ANN. \$§ 84-1901 et seq. (1960), as amended, (Supp. 1973), which was 
and administrability do justify the approach the Court has taken. But cases such as Standard do not involve consumer-type gross receipts taxes. Rather, they involve general business taxes measured by the gross receipts of the enterprise; ${ }^{121}$ like other business taxes, they are neither separately stated nor imposed on a transaction-bytransaction basis. ${ }^{122}$ Hence one may seriously question the appropriateness of a rule for general business taxes which seems to have been developed with consumer taxes in mind. ${ }^{123}$

There appears in fact to be no theoretical justification for deviating from the apportionment principle for determining the taxability of business activity in the state simply because an enterprise's gross receipts, rather than its net income or capital stock, are the measure ${ }^{124}$ of such activity. As Justice Brennan suggested in his dissent in General Motors, "if commercial activity in more than one state results in a sale in one of them, that State may not claim as all its own the gross receipts to which the activity within its borders has contributed only a part." ${ }^{125}$ Indeed, it is startling to find the Court more tolerant of an unapportioned levy measured by gross receipts that "affects each transaction in proportion to its magnitude and irrespective of whether it is profitable or otherwise" ${ }^{126}$ than it would be of such a levy measured by net income

considered in McLeod v. J.E. Dilworth Co., 322 U.S. 327 (1944) . Norton Co. v. Department of Revenue, 340 U.S. 534 (1951), discussed at notes 67-76 supra, involved minois' retailers occupation tax, now ILl. REv. STat. ch. 120, $\$ \$ 440$ et seq. (1974), as amended, (Supp. 1975). While the Court's suggestion that the "tax falls on the vendor," 340 U.S. at 537, is formally accurate, ILL. REv. STat. ch. 120, $\$ 441$ (1974), in fact the tax operates as a retail sales tax, with retailers separately stating the tax, adding it to the price of merchandise sold by them, and collecting it on a transaction-by-transaction basis. 1 CCH ILL. STATE TAX REP. \ 63-001 (1972).

121 Examples are Washington's business and occupation tax, now WASH. REV. CODE ANN. $\$ \S 82.04 .010$ et seq. (1962), as amended, (Supp. 1974), which was considered in General Motors Corp. v. Washington, 377 U.S. 436 (1964), and Gwin, White \& Prince, Inc. v. Henneford, 305 U.S. 434 (1939), see notes 32-33 supra, and Indiana's gross income tax, now IND. ANN. STAT. \$§ 6-2-1-1 et seq. (1972), as amended, (Supp. 1975), which was considered in International Harvester Co. v. Department of Treasury, 322 U.S. 340 (1944) ; J. D. Adams Mfg. Co. v. Storen, 304 U.S. 307 (1938) .

122 Willis Committe Report, supra note 21, at 1009, 1112.

123 Id. at 111 I-12.

124 See note 150 infra.

125 General Motors Corp. v. Washington, 377 U.S. 436, 451 (1964) (Brennan, J., dissenting) .

128 United States Glue Co. v. Town of Oak Creek, 247 U.S. 321,329 (1918); cf. Central Greyhound Lines, Inc. v. Mealey, 334 U.S. 653, 663 (1948) . 
that "does not arise at all unless a gain is shown over and above expenses and losses, and ... cannot be heavy unless the profits are large." 127

There is, however, one more piece in the mosaic that provides a plausible explanation-though not a theoretical justification-for the Court's failure to insist upon true apportionment of general business taxes measured by gross receipts. It has long been established that excise taxes on manufacturing, producing, and extracting activities may be imposed by the states on the unapportioned gross receipts from such activities. ${ }^{128}$ The Court has considered these activities to be "local" ir nature, and it has permitted the states to measure the value of the intrastate activity by the gross receipts therefrom notwithstanding intimate connections between intrastate and interstate activity. Thus, in American Manufacturing Co. v. St. Louis ${ }^{129}$ the Court upheld an excise tax on a manufacturing business measured by the unapportioned value of the products sold even though they were sold in interstate commerce.

Such cases are stumbling blocks in the way of any broad-based apportionment solution to the problem of multiple taxation in the gross receipts tax area. So long as they remain good law, an interstate enterprise might be subject to multiple taxation upon its gross receipts whether or not apportionment is required in cases like Standard Pressed Steel. Justice Goldberg's dissent in General Motors Corp. v. Washington exposes this difficulty. ${ }^{130}$ After indicating that Washington imposes a tax on both manufacturers and wholesalers but exempts the manufacturer from the tax if it has already paid the wholesaler tax, he noted that

an out-of-state firm manufacturing goods in a State having the same taxation provisions as does Washington would be subjected to two taxes on interstate sales to Washington customers. The firm would pay the producing State a local manufacturing tax measured by sales

127 United States Glue Co. v. Town of Oak Creek, 247 U.S. 321, 329 (1918). From an economic standpoint, however, in a perfectly competitive market the overall impact on business behavior of a tax on gross receipts would not be predictably different from the impact of a tax on net income producing the same amount of revenue.

128 American Mfg. Co. v. St. Louis, 250 U.S. 459 (1919) (manufacturing); Heisler v. Thomas Colliery Co., 260 U.S. 245 (1922) (extracting); Hope Natural Gas Co. v. Hall, 274 U.S. 284 (1927) (producing). See Powell, New Light on Gross Receipts Taxes: The Berwind-White Case, 53 HARv. L. REv. 909, 911-12 (1940).

129250 U.S. 459 (1919).

130377 U.S. 436, 451-62 (1964) (Goldberg, J., dissenting). 
receipts and would also pay Washington a tax on wholesale sales to Washington residents. Under such taxation programs, if an out-ofstate manufacturer competes with a Washington manufacturer, the out-of-state manufacturer may be seriously disadvantaged by the duplicative taxation..$^{131}$

Moreover, it is perfectly apparent that apportionment of Washington's gross receipts tax on interstate sales activity would solve only half the problem. If General Motors or Standard Pressed Steel were subject to an unapportioned tax on manufacturing, warehousing, or other activity in a state other than Washington, they would still be taxed on more than 100 percent of the value of their receipts even if Washington apportioned its wholesaling tax. This may suggest that all gross receipts taxes levied upon interstate enterprises should, as a matter of logic, be apportioned whether imposed on interstate sales activity or on "local" production and manufacturing activity. ${ }^{132}$ Yet it may also indicate that the Court viewed the practical implications of disturbing a large and longstanding body of precedent in order to forge an analytically sound apportionment solution in Standard as a hornets' nest from which it wished to maintain a respectful distance. ${ }^{133}$

131 Id. at 460 .

132 But see Willis Commitee Report, supra note 21, at 1114: "Apportionment of gross receipts would introduce numerous complexities into a form of taxation whose chief virtue is simplicity."

133 Id. at 11-14, 1042, 1047; see note 214 infra. This assumes that the Court thought about these matters in the first place, which may be a questionable assumption.

The Standard opinion touched upon one other point that merits brief attention. Since Western Live Stock v. Bureau of Revenue, 303 U.S. 250 (1938), a key criterion for determining the validity of a state tax on an interstate business has been whether the tax imposes a "multi-le" or "cumulative" burden upon interstate commerce. Id. at 255-56; see note 6 supra. As originally formulated, the rule appeared to be couched in the language of possibility rather than certainty, i.e., whether multiple burdens were capable of being imposed, not whether they actually had been. See J.D. Adams Mfg. Co. v. Storen, 304 U.S. 307, 311 (1939); Gwin, White \& Prince, Inc. v. Henneford, 305 US. 434, 440 (1939); Joseph v. Carter \& Weekes Stevedoring Co., 330 U.S. 422, 429 (1947); Central Greyhound Lines, Inc. v. Mealey, 334 U.S. 653, 663 (1948). But the Court took a strikingly different approach in Northwestern States Portland Cement Co. v. Minnesota, 358 US. 450 (1959), where it noted that "[ $t$ ]here is nothing to show that multiple taxation is present, We cannot deal in abstractions. In this type of case the taxpayers must show that the formula places a burden upon interstate commerce in a constitutional sense." Id. at 463. The Court's continued adherence to this "actual burdens" approach in General Motors Corp. v. Washington, 377 U.S. 436, 449 (1964), suggested that the change in doctrine was not inadvertent, especially in light of the vigorous dissent it elicited from Justice Goldberg, who remarked that "if there is to be a limitation on the taxing power of each 
In the end, the apportionment analysis adopted by the Court in Standard proves to be as unrefined a method for identifying the tax base of an interstate enterprise as the nexus analysis criticized earlier. We may nonetheless take some solace in the fact that the body of law to which the Court has turned in these cases, however unsuited to the scrutiny of general business taxes, has the virtue of being relatively settled.

\section{Golonial Pipeline}

In Colonial Pipeline Co. v. Traigle, ${ }^{134}$ as in Standard Pressed. Steel, the Court was treading on familiar ground. ${ }^{135}$ At issue was

of these States, that limitation surely cannot be on a first-come-first-tax basis." Id. at 458 . Nevertheless, eight years later, in Evco v. Jones, 409 U.S. 91 (1972), the Court once again reversed field, quoting language from J.D. Adams concerning the "risk of a double tax burden," id. at 94, without a word about the taxpayer's burden' of showing it had actually been subjected to double taxation. From this one state court concluded that "the 'risk' rule for multiple taxation remains 'the' rule." Michigan Fruit Canners, Inc. v. Department of Treasury, 53 Mich. App. 1, 7, 218 N.W.2d 385, 388 (1974).

In Standard Pressed Steel the Court revealed its latest thinking on this subject:

We noted in General Motors that a vice in a tax on gross receipts of a corporation doing an interstate business is the risk of multiple taxation; but that the burden is on the taxpayer to demonstrate it. . . The corporation made no such showing there. Nor is any effort made to establish it here.

419 U.S. at 563. While invoking the notion of "the risk of multiple taxation" as a criterion for evaluating the validity of a gross receipts tax under the multiple burden standard, the Court nonetheless appears to be adhering to the Northwestern/General Motors approach in refusing to deal in abstractions and insisting that the taxpayer make a palpable showing that the risk exists. Just what the taxpayer must show, however, remains unclear. Standard conceded that Washington's levy did not actually subject it to a multiple tax burden, Jurisdictional Statement at 14 , but argued that it was exposed to the risk that California or Pennsylvania would impose similar taxes measured by its gxoss receipts, thereby creating such a burden. Brief for Appellant at 29-30. The state responded that inasmuch as an unapportioned tax on gross receipts from interstate sales could, under established case law, be imposed solely by the state of destination, neither the actuality nor the risk of multiple burden could exist in the instant case since the state of origin was forbidden from imposing such a levy. Brief for Appellee at 46-47. Although it did not acidress the state's underlying premise that Pennsylvania and California were without power to impose a gross receipts levy on Standard's sales to Washington customers, the Court may have been adopting that position sub silentio in rejecting Standard's argument that it was subject to the risk of multiple taxation. Indeed, if this was not the Court's position, the alternative would be difficult to reconcile with the recent comment in Austin v. New Hampshire, 420 U.S. 656, 668 (1975): "Nor, we may ad" , can the constitutionality of one State's statutes affecting nonresidents depend upon the present configuration of the statutes of another State."

134421 U.S. 100 (1975)

135 See text at notes $30-33$ supra. 
" the perennial problem of the validity of a state tax for the privilege of carrying on, within a state, certain activities' related to a corporation's operation of an interstate business." ${ }^{136}$

\section{A. The Tax-Immune Privilege of Doing Interstate Business- $A$ Bit of Background}

One of the fundamentals of commerce clause learning is that an enterprise doing exclusively interstate business cannot constitutionally be subjected to a state tax imposed on the privilege of doing business in that state. ${ }^{137}$ The doctrine grew out of a logicalbut not necessary ${ }^{138}$-inference the Court drew from the proposition that the commerce clause precludes a state from preventing an out-of-state corporation from engaging in interstate business within its borders. ${ }^{139}$ After concluding that a state was barred from imposing a tax or fee upon a foreign corporation as a condition to commencing business in the state, ${ }^{140}$ the Court extended the principle to forbid a tax on the privilege of doing business, as applied to a foreign corporation doing exclusively interstate business in the taxing state, even though the tax was not levied as a condition to commencing business. ${ }^{141}$ Nor did it make any difference that both foreign and domestic corporations and interstate and intrastate business were taxed on a nondiscriminatory basis. ${ }^{142}$

Over the years, however, as judicial attitudes towards state tax power became more generous, significant inroads were made on the doctrine that the privilege of doing interstate business was immune from state taxation. The Court found taxable "local

136421 U.S. at 101, quoting Memphis Natural Gas Co. v. Stone, 335 U.S. 80, 85 (1948) .

137 Memphis Steam Laundry Cleaner, Inc. v. Stone, 342 U.S. 389, 393 (1952); General Trading Co. v. State Tax Comm'n, 322 U.S. 335, 338 (1944); Atlantic \& Pac. Tel. Co. v. Philadelphia, 190 U.S. 160, 162 (1903) . See generally P. HarTman, supra note 3, at 61-63; Developments, supra note 19 , at 1031.

138 See J. Hellerstein, State Franchise Taxation of Interstate Businesses, 4 TAX L. REv. 95, 99 (1948).

130 Pensacola Tel. Co. v. Western Union Tel. Co., 96 U.S. 1, $12-13$ (1877); see Developments, supra note 19, at 1031; cf. Allenberg Cotton Co. v. Pittman, 419 U.S. 20, 37 (1974) (Rehnquist, J., dissenting).

140 Leloup v. Port of Mobile, 127 U.S. 640, 645 (1888); Western Union Tel. Co. v. Kansas, 216 U.S. 1, 47-48 (1910).

141 Cheney Bros. v. Massachusetts, 246 U.S. 147, 153-54 (1918); Alpha Portland Cement Co. v. Massachusetts, 268 U.S. 203, 217 (1925); see J. Hellerstein, supra note 138, at 99. 142 See note 141 supra. 
incidents" of interstate business activity, and thus chipped away at the scope of the privilege. ${ }^{143}$ It developed the multiple taxation doctrine ${ }^{144}$ that undermined the basis for the tax immunity ${ }^{145}$ and led to distinctions between cases that became increasingly gossamer. ${ }^{146}$ And by summarily affirming several state court decisions that seemingly approved taxes imposed on exclusively interstate business ${ }^{147}$ the Court could have been read as bestowing its own blessing upon such levies.

The high point in these developments was the Court's decision in Northwestern States Portland Cement Co. v. Minnesota. ${ }^{148}$ The Court held that the commerce clause did not preclude a state from imposing a fairly apportioned, nondiscriminatory net income tax upon an out-of-state corporation engaged exclusively in interstate commerce in the taxing state. At the same time, however, the Court reaffirmed its decision in Spector Motor Service $v$. O'Connor, ${ }^{149}$ where it had invalidated a Connecticut tax similar in virtually every respect to the tax at issue in Northwestern except that it was levied on the privilege of doing business in the state. The distinction the Court perceived between the two cases was that the formal subject ${ }^{150}$ of the tax in Northwestern was the corporation's

143 See, e.g., Memphis Natural Gas Co. v. Stone, 335 U.S. 80 (1948) ; Coverdale v. Arkansas-Louisiana Pipe Line Co., 303 U.S. 604 (1938). See generally Strecker, supra note 3.

144 See note 6 supra.

$145 \mathrm{~J}$. Hellerstein, supra note 138, at 101-02.

146 Compare, e.g., Interstate Oil Pipe Line Co. v. Stone, 337 U.S. 662 (1949), with Michigan-Wisconsin Pipe Line Co. v. Calvert, 347 U.S. 157 (1954).

147 Field Enterprises, Inc. v. State, 47 Wash. 2d 852, 289 P.2d 1010 (1955), aff'd per curiam, 352 U.S. 806 (1956); West Publishing Co. v. McColgan, 27 Cal. 2d 705, I66 P.2d 861 , aff'd per curiam, 328 U.S. 823 (1946). The Field Enterprises case is discussed at notes 77-82 supra; the West Publishing case involved the imposition upon West of California's corporate income tax, which was sustained in part on the ground that "a tax on net income from interstate commerce, as distinguished from a tax on the privilege of engaging in interstate commerce, does not conflict with the commerce clause." 27 Cal. 2d at 709, 166 P.2d at 863. Cf. Stone v. Interstate Natural Gas Co., I03 F.2d 544 (5th Cir.), aff'd per curiam, 308 U.S. 522 (1939).

148358 U.S. 450 (1959).

149340 U.S. 602 (1951). The Northwestern Court stated that it was "beyond dispute that a State may not lay a tax on the 'privilege' of engaging in interstate commerce," and cited Spector. 358 U.S. at 458.

150 The subject is the legal incidence of a tax. It is the thing or event upon which the power to tax is based; the measure of a tax is the yardstick to which the rate is applied. Subject and measure may be distinct, as in a privilege tax, where the subject is the privilege and the measure is, for example, income; or subject and measure may coincide, as in an income tax, where the income is both the subject upon which the tax power is predicated 
net income, whereas in Spector it was the privilege of doing business. By continuing to adhere to the holding of Spector, that the commerce clause bars a state from levying a privilege tax, regardless of its measure, upon a corporation engaged exclusively in interstate commerce within the taxing state, the Court in Northwestern attributed constitutional import to a distinction that lacked economic significance. ${ }^{151}$ Since the measure of the levies at issue in both Spector and Northwestern was the corporation's net income, the immunity that exclusively interstate commerce enjoyed from state taxation apparently depended on whether the legislative draftsmen called the tax by the right name. ${ }^{152}$

Finally, a growing number of state court decisions that the Supreme Court chose not to disturb in those instances when it was given an opportunity to do so reinforced the conclusion that the commerce clause was no bar to the assertion of a state tax upon exclusively interstate business, when exerted on an apportioned and nondiscriminatory basis, if state legislators were sufficiently sophisticated and state courts sufficiently creative. One court upheld such a tax because it was laid on the right to do business in the "corporate form" as opposed to the privilege of doing business; ${ }^{153}$ another did so because the privileges taxed-exercising a corporate franchise, owning property, employing capital, maintaining an office-were distinct from the privilege of engaging in

and the basis upon which the amount due is calculated. It is the subject of a tax which has constitutional significance; the measure, at least in theory, has not presented constitutional questions. See, e.g., Atlantic Ref. Co. v. Virginia, 302 U.S. 22, 26-27 (1937); Kansas City, F.S. \& M. Ry. v. Botkin, 240 U.S. 227, 233 (1916). But the Court has occasionally attributed constitutional import to the measure of a tax by obscuring the distinction between subject and measure. See, e.g., Gwin, White \& Prince, Inc. v. Henneford, 305 U.S. 434, $438-40$ (1939); New Jersey Bell Tel. Co. v. State Bd. of Taxes, 280 U.S. 338, 348-49 (1930) . See generally Developments, supra note 19, at 960-61.

151 It is true, however, that United States obligations or interest therefrom would be exempt from state taxation under a direct net income tax but not under a nondiscriminatory franchise tax. 31 U.S.C. \$ 742 (1970). See Reuben L. Anderson-Cherne, Inc. v. Commissioner, — Minn. —- 226 N.W.2d 611, appeal dismissed, 96 S. Ct. 181 (1975) .

152 Comment, State Taxation of Interstate Commerce: Roadway Express, the Diminishing Privilege Tax Immunity, and the Movement Toward Uniformity in Apportionment, 36 U. CHI. L. REv. 186, 187-88 (1968) .

153 Texas Gas Transmission Corp. v. Atkins, 197 Tenn. 123, 129, 270 S.W.2d 384, 387, cert. denied, 348 U.S. 883 (1954). See also Mid-Valley Pipeline Co. v. King, 221 Tenn. 724, 431 S.W.2d 277 (1968), appeal dismissed, 393 U.S. 321 (1969); Texas Gas Transmission Corp. v. Atkins, 205 Tenn. 495, 327 S.W.2d 305 (1959). 
business "as such"; ${ }^{154}$ a third upheld the tax in part on the distinction between the "right to exist" in a state and the privilege of doing business there. ${ }^{155}$ Another court in effect rejected the distinction altogether. ${ }^{156}$

When the Court noted probable jurisdiction in Colonial, which raised the privilege issue almost precisely as it had been raised by a case decided 25 years earlier, ${ }^{157}$ one might have surmised that the Court was intent upon rehabilitating the privilege or, alternatively, abandoning it once and for all.

\section{B. The Decision}

The Colonial Pipeline Company, a Delaware corporation with its principal place of business in Atlanta, Georgia, owned and operated a pipeline which carried liquid petroleum from Houston, Texas, to the New York City area. Two hundred fifty-eight miles of the 3,400 mile pipeline were located in Louisiana, as were a number of pumping stations and storage tanks. Colonial also employed a work force in the state of some 25 to 30 mechanics, electricians, and other personnel to service and inspect the line. However, the company had no administrative offices or personnel in Louisiana and did no intrastate business in petroleum products there. ${ }^{158}$ Louisiana imposed a variety of levies upon Colonial, ${ }^{159}$ including its franchise tax, ${ }^{160}$ which was measured by the value of the taxpayer's capital stock, surplus, and undivided profits. The state's earlier efforts to tax Colonial under a previous version of

154 Roadway Express, Inc. v. Director, 50 N.J. 471, 489, 236 A.2d 577, 586 (1967), appeal dismissed, 390 U.S. 745 (1968). See generally Comment, supra note 152.

155 Great Lakes Pipe Line Co. v. Tax Comm'n, 204 Okla. 518, 523, 231 P.2d 655, 661 (1951). No review in the Supreme Court seems to have been sought in this case.

150 United Air Lines, Inc. v. Porterfield, 28 Ohio 2d 97, 100, 276 N.E.2d 629, 632-33 (1971), appeal dismissed, 407 U.S. 917 (1972). See also Cooper-Jarrett, Inc. v. Porterfield, 15 Ohio 2d 54, 238 N.E.2d 554 (I968).

157 Memphis Natural Gas Co. v. Stone, 335 U.S. 80 (1948). See text accompanying notes 77-83 supra.

158 In its operation in Louisiana, Colonial has apparently done no intrastate shipping of petroleum products. Loads or batches are picked up outside the state and deposited within the state, and picked up within the state for transportation elsewhere.

Colonial Pipeline Co. v. Agerton, 289 So. 2d 93, 94 (La. 1974).

159 Among them were its ad valorem, property, use, and income taxes. See Colonial Pipeline Co. v. Mouton, 228 So. 2d 718, 720 nn. 2-4 (La. Ct. App. 1969).

160 LA. REv. Star. ANN. § 47:601 (1970), as amended, (Supp. 1975). 
the same statute had been unsuccessful, ${ }^{161}$ and it is necessary to trace the history of these efforts to appreciate the import of the Supreme Court's determination regarding the constitutionality of the statute before it.

Until 1970 Louisiana's franchise tax was imposed upon every domestic and foreign corporation "for the privilege of carrying on or doing business, the exercising of its charter or the continuance of its charter within this state, or owning or using any part or all of its capital or plant in this state." ${ }^{162}$ When Colonial commenced its operations in Louisiana in 1962, the state sought to impose this tax. ${ }^{103}$ Colonial challenged the levy and prevailed in Louisiana's intermediate appellate court, which held that the tax as applied to Colonial violated the commerce clause since it was "levied squarely upon the privilege of engaging in business in Louisiana" 164 and Colonial was "engaged solely in interstate commerce." 165

The Louisiana legislature responded to this decision by amending the franchise tax statute. It eliminated the clause that made "the privilege of carrying on or doing business" a subject of the tax and substituted the clause, "[ $\mathrm{t}]$ he qualification to carry on or do business in this state or the actual doing of business within this state in a corporate form." 166 The other two taxable incidentsthe exercise or continuance of the corporate charter and the ownership or use of capital or plant in the state-were retained from the earlier version of the statute. Once again the state sought to impose its franchise tax on Colonial, and once again Colonial prevailed in Louisiana's intermediate appellate court, which saw no palpable distinction between this case and the case it had decided three years earlier. ${ }^{167}$ The court was unimpressed by the Louisiana

161 Colonial Pipeline Co. v. Mouton, 228 So. 2d 718 (La. Ct. App. 1969), writ denied, 255 La. 474, 231 So. 2d 393 (1970).

162 LA. REv. Stat. ANN. § 47:601 (1970), as amended, (Supp. 1975).

163 Colonial Pipeline Co. v. Mouton, 228 So. $2 d 718$ (La. Ct. App. 1969).

164 Id. at 723.

$165 \mathrm{Id}$. at 721 . The Supreme Court of Louisiana declined to review the case. $255 \mathrm{La}$. 474,231 So. 2 d 393 (1970). This, that court later explained, was a fact of persuasive but not precedential proportion. See Colonial Pipeline Co. v. Agerton, 289 So. 2d 93, 96 (La. 1974).

166 Act of July 13, 1970, No. 325, § 1, [1970] La. Acts 856 (codified at LA. Rev. Stat. ANN. § 47:601 (Supp. 1975)).

167 Colonial Pipeline Co. v. Agerton, 275 So. $2 d 834$ (La. Ct. App. 1973) . It was stipulated that Colonial's operations in Louisiana had not changed since the earlier decision. Id. at 836 . 
legislature's efforts and characterized them as "nothing more than a rephrasing of the general language contained in [the statute] prior to its amendment in 1970." 168

But the Supreme Court of Louisiana disagreed. ${ }^{169}$ It pointed to the omission in the amended statute of the "primary operating incident" of the original statute, i.e., "the privilege of carrying on or doing business," ${ }^{170}$ noting that "[t]he thrust of the [amended] statute is to tax not the interstate business done in Louisiana by a foreign corporation, but the doing of business in Louisiana in a corporate form, including 'each and every act, power, right, privilege, or immunity exercised or enjoyed in this state, as an incident to or by virtue of the powers and privileges acquired by the nature of such organizations." " 171 It concluded that a tax on the doing of business in the corporate form in the state was "sufficiently distinguishable" from a tax on the privilege of doing business in the state to satisfy the strictures of the commerce clause. ${ }^{172}$

The taxpayer appealed to the United States Supreme Court. No question was raised about the reasonableness of the apportionment, as determined by an appropriate formula, of the capital employed by Colonial in Louisiana. Nor was there any contention that the tax discriminated against Colonial. And it was conceded that Colonial's business in Louisiana was exclusively interstate. ${ }^{173}$ The issue before the Court was therefore clear: can a state impose a nondiscriminatory, fairly apportioned franchise tax upon an exclusively interstate business for doing business in the corporate form in the state? The resolution of this narrow issue, however, seemed to carry inescapable implications for the resolution of the broader question of whether the tax-immune privilege of doing business was to survive as a viable concept.

Indeed, if resolution of this broader question were not what the Supreme Court had in mind when it decided to give the case plenary consideration, it is puzzling why it bothered to do so. Some 25 years earlier, in Memphis Natural Gas Co. v. Stone, ${ }^{174}$ the Court

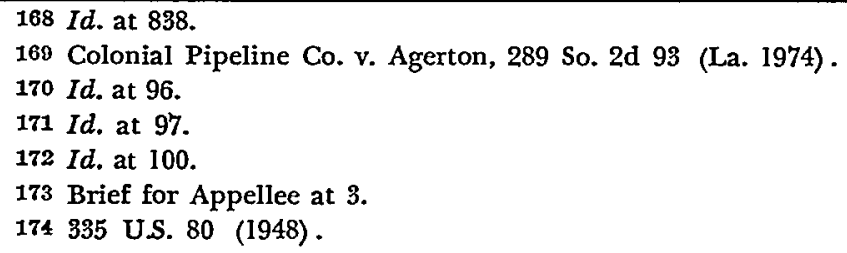


had upheld a Mississippi franchise tax upon facts as close to Colonial as any lawyer looking for controlling precedent could ever hope to find. Memphis owned and operated an interstate pipeline for the transportation of natural gas; Colonial owned and operated an interstate pipeline for the transportation of liquified petroleum products. Memphis maintained 135 miles of its pipeline in Mississippi, where it engaged exclusively in interstate commerce; Colonial maintained 258 miles of its pipeline in Louisiana, where it also engaged exclusively in interstate commerce. ${ }^{175} \mathrm{Mem}-$ phis had no office in Mississippi, and its only employees there were those necessary to maintain its pipeline and compressing stations; Colonial maintained no office in Louisiana, and its only employees there were those necessary to maintain its pipeline and pumping stations. ${ }^{176}$

Mississippi imposed a franchise tax upon, inter alia, every foreign corporation "doing business" in the state, defined "[to] mean and [to] include each and every act, power or privilege exercised or enjoyed in this State, as an incident to, or by virtue of the powers and privileges acquired by the nature of such organization," for "the benefit and protection of the government and laws of the state" that the corporation received; ${ }^{177}$ Louisiana imposed a franchise tax upon, inter alia, every foreign corporation "doing business" in the state, defined to "mean and include each and every act, power, right, privilege, or immunity exercised or enjoyed in this state, as an incident to or by virtue of the powers and privileges acquired by the nature of such organizatio[n]," "for the enjoyment, under the protection of the laws of this state, of the powers, rights, privileges and immunities derived by reason of the corporate form of existence and operation." ${ }^{178}$ The Supreme Court of Mississippi held in part that its tax was "an exaction ... as a recompense for its protection of ... the local activities in maintaining, keeping in

175 Memphis had one customer in Mississippi to which it sold gas from its interstate line at wholesale from several delivery points. $I d$. at 81 . Colonial had a number of customers in Louisiana, but all deliveries of petroleum products into Lonisiana originated outside the state. 289 So. $2 \mathrm{~d}$ at $94-95$.

170 Colonial had once maintained a division office in Baton Rouge prior to the tax years in question. 421 U.S. at 102.

177 Act of March 14, 1934, ch. 121, §§ 1-2, [1934] Miss. Acts 204 (now Miss. Cone AnN. $\$$ 27-13-1, 27-13-7 (1972)).

178 LA. Rev. Stat. ANN. \$ 47:601 (Supp. 1975). 
repair, and otherwise in manning the facilities of the system throughout the 135 miles of its line in this State"; ${ }^{179}$ the Supreme Court of Louisiana held in part that its tax was "an exaction ... as a recompense for its protection of ... the local activities in maintaining, keeping in repair, and otherwise in manning the facilities of th[e] pipeline system throughout the 258 miles of its pipeline in the State of Louisiana." 180

There was no cause for surprise, then, when the Supreme Court, relying principally on its decision in Memphis Natural Gas, affirmed the Louisiana Supreme Court's decision in Colonial. ${ }^{181}$ The Court held that a fairly apportioned nondiscriminatory franchise tax could constitutionally be levied upon an exclusively interstate enterprise for the doing of business in corporate form, since such a tax was not imposed "merely or solely" for the privilege of doing business in Louisiana. ${ }^{182}$ In substance, the Court seemed to be saying that where local activities are sufficient to justify the state's taxing a corporation for the privilege of engaging in such activities -in Colonial, as in Memphis, the maintenance of property and employees in the state to service an exclusively interstate pipelinethe state may alternatively levy the tax on the "privileges" associated with the taxpayer's corporate existence within the state. ${ }^{183}$

179 Stone v. Memphis Natural Cas Co., 201 Miss. 670, 674, 29 So. 2d 268, 270 (1947). 180289 So. $2 \mathrm{~d}$ at $100-01$.

181421 U.S. 100 (1975). Justice Blackmun, whom Justice Rehnquist joined, wrote a separate opinion concurring in the result. $I d$. at 114-16. Justice Stewart wrote a dissenting opinion. Id. at 116. Justice Douglas did not participate in the case.

182 Id. at 114.

183 The Court also appeared to give some weight to the fact that Colonial had voluntarily qualified to do business in Louisiana, stating that this fact made its conclusion "even more compelled" than it was in Memphis, where the taxpayer had not qualified to do business in the state. Id. at 111. Precisely what the Court meant by this remark, however, is unclear. The Court has been less than consistent in its position as to whether qualification itself is a sufficient "Iocal incident" upon which to predicate a franchise tax upon an exclusively interstate business. Compare Interstate Natural Gas Co. v. Stone, 308 U.S. 522, aff'g per curiam 103 F.2d 544 (5th Cir. 1939), with Anglo-Chilean Nitrate Sales Corp. v. Alabama, 288 U.S. 218, 224-25 (1933), and Ozark Pipe Line Corp. v. Monier, 266 U.S. 555, 566-67 (1925). See Memphis Natural Gas Co. v. Stone, 335 U.S. 80, $89-93$ (1948) . While the Court may have deemed it significant in Colonial that Louisiana made "qualification to carry on or do business in this state" one of the local incidents upon which its tax was levied, LA. Rev. Srat. ANn. § 47:601 (Supp. 1975), the Louisiana Supreme Court made only passing reference to this fact and rested its holding instead on the existence of the taxable local incident of the doing of business in Louisiana in corporate form, 289 So. 2d at 96, 97, 100, as the Supreme Court recognized. 421 U.S. at 105, 106, 109. Moreover, the extent to which unqualified foreign corporations engaged in exclusively interstate 
What was surprising, however, was the Court's failure to confront the underlying issue of the continuing vitality of the taximmune status of the privilege of doing interstate business. Instead, the Court engaged in the semantic exercise of distinguishing the doing of business in the corporate form from the bare privilege of doing business. It pointed to the "privileges" associated with corporate existence ${ }^{184}$ and noted that these "obviously enhance the value to [Colonial] of its activities within Louisiana." ${ }^{185}$ Quite different, in the Court's view, were levies such as those at issue in Spector and the first Colonial case, which suffered from the "fatal constitutional flaw" 186 that they were imposed on the privilege of doing business-even though these were virtually ${ }^{187}$ identical in economic impact to those taxes to which it had given its approval. If "[i]t is not a matter of labels," ${ }^{188}$ as the Court insisted, then it was a matter of elusive "incidents," 189 "incidences," ${ }^{190}$ and "thrusts"'191

commerce may constitutionally be denied the privileges accorded qualified foreign corporations is open to question. See Allenberg Cotton Co. v. Pittman, 419 U.S. 20, 33-34 (1974) . Finally, in the absence of dispositive constitutional considerations on either side of the issue, one might question the desirability of making mere qualification a taxable local incident justifying imposition of a state's franchise tax upon an exclusively interstate business. Since the states lack power to compel qualification by a foreign corporation engaged exclusively in interstate commerce, Crutcher v. Kentucky, 141 U.S. 47 (1891), and since qualification facilitates assessment and collection of state taxes, Comment, Foreign Corporations_State Boundaries for National Business, 59 YALE L.J. 737, 746 (1950), as the Court specifically acknowledged, 42I U.S. at $11 \mathrm{l}-12 \mathrm{n} .8$, a rule that makes a qualified corporation liable for a franchise tax it might have avoided had it not qualified could well be counterproductive. For it would tend to discourage corporations doing exclusively interstate business from qualifying and thus disserve other interests of the states, see Comment, supra, at 146, including collection of taxes the corporation could not resist on commerce clause grounds. See note 159 supra and accompanying text.

184 These included "the legal status to sue and be sned in the Courts of our State, continuity of business without interruption by death or dissolution, transfer of property interests by the disposition of shares of stock, advantages of business controlled and managed by corporate directors, and the general absence of individual liability." 421 U.S. at 112 , quoting 289 So. $2 \mathrm{~d}$ at 100.

185421 U.S. at 112.

186 Id.

187 See note 151 supra.

188421 U.S. at 113, quoting Spector Motor Service, Inc. v. O'Connor, 340 U.S. 602, 608 (1951).

189421 U.S. at 113 n.9.

190 Id. at 109,113 . This is not to suggest that the economic incidence of a tax is unimportant; the Court's references, however, were to legal "incidences" bearing no necessary relation to economic reality. $I d$.

191 Id. at 113 . 
that are apparently perceptible only to the most advanced constitutional thinkers.

Perhaps one could read the Court's opinion more charitably as laying the groundwork for a new departure in commerce clause doctrine. The great weight attributed to the taxpayer's corporate status might be viewed as pointing to the propriety, under the commerce clause, of applying one set of standards to state taxes on the privilege of doing business in the case of corporations and another in the case of unincorporated enterprises. Such a differentiation, although of questionable economic significance, would nevertheless reflect the facts that the states have long subjected corporations to business taxes different from those imposed on individuals and partnerships, ${ }^{192}$ and that interstate business is dominated by corporations. ${ }^{193}$ Whatever the merits of such an approach, however, it is not even hinted at in the Colonial opinion. None of the cases considered, including those the Court distinguished, raised the issue; indeed, all but one ${ }^{194}$ involved corporations. Furthermore, the concurring and dissenting opinions both cast doubt on the distinction. ${ }^{195}$ It is therefore highly improbable that the Court intended sub silentio to embrace the suggested rationale.

\section{The Tax-Immune Privilege of Doing Interstate Business- An Obituary}

The root of the difficulty in making sense out of the Court's opinion in Colonial lies in the fact that it amounts essentially to a reductio ad absurdum of its own precedents. In Memphis Gas the Court had found that the "local incidents" of maintaining an interstate pipeline, though admittedly essential to the conduct of that interstate business, ${ }^{196}$ were sufficiently separate-"apart from the flow of commerce" ${ }^{197}$-to be distinguishable from the privilege of doing business. In General Motors the Court likewise isolated the "local incidents" of establishing and maintaining a sales force as

192 Compare, e.g., N.Y. TAX LAw arts. 9, 9A (McKinney 1966), as amended, (McKinney Supp. 1975), with id. arts. 16-A, 23 (McKinney 1975), as amended, (McKinney Supp. 1975).

193 See text at note 199 infra.

194 Western Live Stock v. Bureau of Revenue, 303 U.S. 250 (1938).

195421 U.S. at 115-16. See text accompanying note 196 infra.

196335 U.S. 80, 96 (1948).

197 Id., quoting Spector Motor Serv., Inc. v. O'Connor, 340 U.S. 602, 609 (1951) . 
sufficiently distinct aspects "of his [interstate] business which, unlike the privilege of doing interstate business, are subject to the sovereign power of the state." ${ }^{198}$ In Colonial the Court, by once again fractionating the concept of doing business so as to create a discrete taxable element that could be differentiated from the taximmune privilege of doing business, for all practical purposes extinguished the privilege itself. To deny that the doing of business in the corporate form is embodied within the privilege of doing business guts the privilege entirely. It is no secret that interstate business is carried on primarily by corporations. Indeed, as of 1965 corporate manufacturing and mercantile activity accounted for 82 percent of all business receipts and 75 percent of all net income originating in these industries. ${ }^{199}$ Moreover, by extending the Court's reasoning to distinguish the ownership of property, use of capital, or employment of personnel in a state from the privilege of doing business in the state, one could, in principle, limit the privilege even further to the unincorporated association owning no property in a state where it has no employees. Or, more simply, as Justice Stewart suggested in dissent, one could impose a tax upon an exclusively interstate enterprise doing business in any form "[f]or, whatever its form, the exclusively interstate business would still be 'owning or using [a] part of its capital, plant, or other property in Louisiana' ... and would still be 'furnished' equivalent 'protection and benefits' by the State. . . ." 200

Furthermore, Colonial itself represents the most dramatic possible illustration of the fact that the tax-immune privilege of doing interstate business has become an illusory abstraction, i.e., the case where a state legislature, with a minimum of wordsmithing, was able to tax the very interstate taxpayer that had successfully resisted imposition of an otherwise identical levy upon identical facts. By approving the amended statute in Colonial, the Court was indeed putting its imprimatur upon "taxation by semantics." 201

Nonetheless, there can be little quarrel with the result in Colonial. Colonial was present in Louisiana, was treated no worse for tax purposes than domestic corporations, and was paying taxes only

108377 U.S. 436,447 (1964) (brackets in original). The case is discussed at notes $83-88$ supra.

190 Wruls Commitree RePort, supra note 21 , at 17.

200421 U.S. at 116 (Stewart, J., dissenting) .

201 Id. at 115 (Blackmun, J., concurring). 
on that portion of its tax base fairly attributable to Louisiana. If one accepts the principle that an enterprise is entitled to no special tax advantage simply because it does business across state lines, ${ }^{202}$ then there would appear to be no persuasive objection to the imposition of "nondiscriminatory, properly apportioned state corporate taxes upon foreign corporations doing an exclusively interstate business" ${ }^{203}$ so long as the requisite nexus requirements are satisfied. ${ }^{204}$ This conclusion simply recognizes that a state should be entitled to demand from an enterprise that carries on business there "its just share of the cost of state government upon which [it] necessarily relies and by which it is furnished protection and benefits" ${ }^{205}$ with respect to the property it owns, the personnel it employs, or the market it exploits.

In the end, while Justice Stewart properly upbraided the Court for its "specious reasoning," 206 it is unlikely that the respect the Court paid to the tax-immune privilege of doing interstate business will mislead anybody. After reading Colonial, only the most sanguine taxpayer would conclude that the Court maintains a serious belief in the doctrine that the privilege of doing interstate business is immune from state taxation. And in light of the compelling case for abandoning it altogether in favor of the position the Court has in effect adopted, ${ }^{207}$ the demise of the doctrine (or its comatose condition) is no cause for grief.

\section{State Taxation of Interstate Business and the Court: Some Final Thoughts on Standard and Colonial}

After the opinions have been dissected, the analytical points made, and the discussion peppered with the requisite number of

202 See P. Hartman, supra note 3, at I2I; J. Hellerstein, supra note 20, at 162; Note, State Taxation of Multistate Businesses, 74 YALE L.J. 1259 (I965).

203 This was the Court's description of the class of levies it has sustained, particularly in recent decades. 42I U.S. at 108. The word "properly" in the quoted phrase should probably have been italicized, since there is no justification for subjecting the interstate corporation to a tax on more than one hundred percent of its tax base as a result of inconsistent state apportionment formulas. See generally Comment, supra note 152, at 204-18. 204 See text at notes 64-65 supra. This was essentially the position taken by Justice Blackmun, who would have overruled Spector. 421 U.S. at II5 (Blackmun, J., concurring) . 205 42I U.S. at II 4.

208 Id. at 116 (Stewart, J., dissenting).

207 See Comment, supra note 152, at 203-04. 
footnotes, ${ }^{208}$ the broader questions raised by Standard and Colonial remain. Why did the Supreme Court take the cases in the first place if they raised "frivolous" questions ${ }^{209}$ or questions clearly controlled by precedent? ${ }^{210}$ And what do the decisions mean in terms of the Court's present attitude toward and role in controversies over the power of states to tax interstate enterprises?

Before the Court handed down its opinions, it would have been reasonable to speculate that, in taking these two cases, the Court intended to use them as a vehicle for an expression of its views on the scope of the commerce and due process clause limitations upon state taxation of interstate business, something it has done relatively infrequently in recent years. ${ }^{21}$ But the opinions seem to belie this theory, since they do little more than repeat the timeworn shibboleths that have created much "controversy and confusion and little in the way of precise guides to the States in the exercise of their indispensable power of taxation." ${ }^{212}$ It is, of course, conceivable that the Court was simply doing its best, that the pressure of time and preoccupation with such momentous issues as sex discrimination, ${ }^{213}$ students' rights, ${ }^{214}$ and environmental protection ${ }^{215}$ left little energy for the mundane problems of state taxation of interstate business, and that we should therefore not "shoot the piano player." 216

There may, however, be a more fundamental explanation-one that bears more directly on the substantive problems with which the Court was confronted-for its performance in Standard and

208 Professor Blum has suggested seven per page as a minimum. W. Blum, The New Consumerism and the Law School 7, 1975 (printed in the series, Occasional Papers from the Law School of the University of Chicago).

209 See text at note 48 supra.

210 See text at notes 174-80 supra.

211 See text at notes 11-29 supra.

212 Northwestern States Portland Cement Co. v. Minnesota, 358 U.S. 450, 457 (1959)

213 Stanton v. Stanton, 421 U.S. 7 (1975); Weinberger v. Wiesenfeld, 420 U.S. 636 (1975); Taylor v. Louisiana, 419 U.S. 522 (1975); Schlesinger v. Ballard, 419 U.S. 498 (1975).

214 Wood v. Strickland, 420 U.S. 308 (1975); Goss v. Lopez, 419 U.S. 565 (1975).

215 Aberdeen \& Rockfish R.R. v. SCRAP, 422 U.S. 289 (1975); Train v. Natural Resources Defense Council, Inc.; 421 U.S. 60 (1975) ; Train v. City of New York, 420 U.S. 35 (1975).

216 Kurland, Foreword: "Equal in Origin and Equal in Title to the Legislative and Executive Branches of the Government," The Supreme Court, 1963 Term, 78 HARv. L. REv. 143,176 (1964). 
Colonial. Perhaps the Court noted probable jurisdiction in these two cases with the thought that they did indeed raise basic problems with respect to the constitutional limitations on state tax authority over interstate business. Perhaps after taking another look at these "perennial" problems, it in effect concluded that over the course of the 150 years during which it had handed down scores of decisions on these or closely related questions, it had accomplished substantially what it was capable of accomplishing in the area. Perhaps the Court further concluded that what it had accomplished struck a fair balance between the key competing interests-those of the states for a contribution to the costs of government from enterprises enjoying benefits within their borders and those of the federal system for the maintenance of a free flow of commerce among the states. And perhaps the Court finally concluded that further improvements or refinements in the balance were beyond the pale of judicial competence ${ }^{217}$ and must come, if at all, from other bodies.

All this, of course, is speculation. However, it is the kind of speculation that lawyers get paid for doing, and there is some evidence to suggest that these decisions mark a strategic retreat by the Court from the battles that once raged over the scope of the constitutional limitations upon the states' power to tax an interstate enterprise. First, there was but a single dissenting opinion in the course of the two decisions, although both raised issues that had sharply divided the Court in the recent past. The principal precedent upon which the unanimous Court in Standard Pressed Steel relied as "almost precisely in point" was the 5-4 decision in General Motors Corp. v. Washington, ${ }^{218}$ decided a decade earlier, and the principal precedent upon which the majority in Colonial Pipeline relied was the three-man plurality opinion in Memphis Natural Gas Co. $v$. Stone ${ }^{219}$ which had been joined by two concurrences and opposed by four dissents. The present near-

217 The inadequacy of the judicial process to deal with the problems of multistate taxation has long been recognized by members of the Supreme Court. In recent years, jurists with such varied philosophies as Justices Jackson, Rutledge, Black, Frankfurter, Douglas, and Clark, have all subscribed to this view and have either directly or implicitly called upon Congress to act.

Willis Commitre Report, supra note 21 , at 13 (footnotes omitted). See generally id. at 11-14; Barrett, supra note 118, at 755-56.

218377 U.S. 436 (1964).

219335 U.S. 80 (1948). 
unanimity of the Court thus represents a dramatic departure from its past performance in this area, which was described a few years ago in the following terms:

The present posture of the Court is characteristic of its entire history in dealing with Commerce Clause tax issues-the great issues involved reflect sharp differences in approach among the Justices, the leading cases are decided by slim majorities over strong dissent, and both the rationale and holdings are fluid and dynamic, with one decade's minority becoming the next decade's majority, only to be displaced in another decade by a new majority. ${ }^{220}$

Moreover, this new harmony may not be attributed simply to the shifting membership on the bench. ${ }^{221}$

Additional pieces of evidence emerge from the nature and quality of opinions in the cases. Their failure to address the underlying questions and their unembarrassed reliance upon discredited doctrine seem to reflect the Court's intellectual exhaustion with the issues raised. And for a Court that has not spared the printer when it comes to issues in which it has a strong interest, ${ }^{222}$ one can reasonably infer that its willingness to do so on issues that once commanded such interest reveals an altered attitude.

Finally, there are the holdings of the cases. Both Standard and Colonial represented an extension of the state's taxing power over interstate business to or beyond the limits that the Supreme Court had previously countenanced under the commerce and due process clauses. By approving the imposition of an unapportioned gross receipts tax upon an interstate business predicated upon the activities of a single in-state employee, Standard substantially reduced the interstate taxpayer's ability to resist such a tax. By approving the imposition of a franchise tax on an exclusively interstate business for the privilege of doing business in the corporate form, Colonial narrowed the tax-immune privilege of doing business to the vanishing point. If the Court were determined to continue to

220 J. HeILERSTEIN, supra note 4, at 169.

221 Justices Brennan, Stewart, and White, who dissented in General Motors, joined the majority in Standard Pressed Steel.

222 San Antonio Independent School Dist. v. Rodriguez, 411 U.S. I (1973) (public school financing, 137 pages); Roe v. Wade, 410 U.S. 113 (1973), and Doe v. Bolton, 410 U.S. 179 (1973) (abortion, 111 pages); Furman v. Georgia, 408 U.S. 238 (1972) (capital punishment, 283 pages) . 
play an active role in policing the exercise of state taxing power over interstate business, it is hardly likely that it would have had so little difficulty in upholding the state court decisions in Standard and Colonial.

In sum, while the Court's adoption of a policy of "benign neglect" towards state taxation of interstate business has hardly been established, there is sufficient evidence in the record to suggest the possibility. ${ }^{223}$ Conceivably the Court has been influenced by the collaborative efforts of the states in recent years and by the prospects of congressional Iegislation designed to achieve a greater degree of uniformity in state taxation of interstate business. ${ }^{24}$ While the success of such efforts had thus far been limited, they offer at least the possibility of comprehensive solutions to the basic problems in this field, something the judiciary-even at its most resourceful-is institutionally incapable of providing. ${ }^{225}$

223 The Court's behavior thus far this term lends further support to this view. The Court has not only refused to review cases sustaining broad assertions of state tax power over interstate business, Johns-Manville Prods. Corp. v. Commissioner, __ N.H.

343 A.2d 221 (1975), appeal dismissed, 44 U.S.L.W. 3415 (U.S. Jan. 20, 1976); Covington Fabrics Corp. v. State Tax Comm'n, 264 S.C. 59, 212 S.E.2d 574, appeal dismissed, 96 S. Ct. 14 (1975), but it also permitted a significant expansion of state tax power in a related area by overruling Low v. Austin, 80 U.S. (13 Wall.) 29 (1871), and holding that the import-export clause is no bar to the imposition of a state's nondiscriminatory ad valorem property tax on imported goods. Michelin Tire Corp. v. Wages, 96 S. Ct. 535 (1976) .

224 See note 22 supra.

225 See note 217 supra. 